\title{
Tectonics
}

\author{
RESEARCH ARTICLE \\ 10.1029/2019TC005501 \\ Key Points: \\ - The Esmeraldas Canyon (EC) \\ started incising the Manglares Basin \\ $\sim 5.3 \mathrm{Ma}$ ago contemporarily with \\ the Carnegie Ridge subduction \\ initiation \\ - The EC migration and incisions \\ reveal Plio-Quaternary fore-arc \\ uplift episodes and the conspicuous \\ influence of glacioeustatic variations \\ - The Ancon Canyon, the main \\ spillway of the Manglares fore-arc \\ basin, was abandoned 170 kyr ago \\ favoring the basin infill
}

Correspondence to:

J.-Y. Collot,

jean-yves.collot@ird.fr

Citation:

Collot, J.-Y., Ratzov, G., Silva, P., Proust, J.-N., Migeon, S., Hernandez, M.-J., et al (2019). The Esmeraldas Canyon: A helpful marker of the Pliocene-Pleistocene tectonic deformation of the North Ecuador-southwest Colombia convergent margin. Tectonics, 38, 3140-3166. https://doi.org/10.1029/2019TC005501

Received 24 JAN 2019 Accepted 22 JUL 2019 Accepted article online 31 JUL 2019 Published online 24 AUG 2019

Corrected 4 SEPT 2019

This article was corrected on 4 SEPT 2019. See the end of the full text for details.

(C)2019. American Geophysical Union. All Rights Reserved.

\section{The Esmeraldas Canyon: A Helpful Marker of the Pliocene-Pleistocene Tectonic Deformation of the North Ecuador-Southwest Colombia Convergent Margin}

\author{
J.-Y. Collot ${ }^{1}$ (D) G. Ratzov' ${ }^{1}$, P. Silva ${ }^{2}$, J.-N. Proust ${ }^{1,3}$ (D) S. Migeon ${ }^{1,4}$, M.-J. Hernandez ${ }^{1,4,5}$, \\ F. Michaud ${ }^{1,4}$, A. Pazmino ${ }^{6}$, D. Barba Castillo ${ }^{7}$, A. Alvarado ${ }^{2}$ (D) and S. Khumara ${ }^{1,8}$ \\ ${ }^{1}$ Université Côte d'Azur, IRD, CNRS, Observatoire de la Côte d'Azur, Valbonne, France, ${ }^{2}$ Instituto Geofísico, Escuela \\ Politécnica Nacional, Quito, Ecuador, ${ }^{3}$ Université de Rennes, CNRS, UMR6118, Geosciences, Rennes, France, ${ }^{4}$ Sorbonne \\ Université, Paris, France, ${ }^{5}$ Departamento de Geología, Escuela Politécnica Nacional, Quito, Ecuador, ${ }^{6}$ Instituto \\ Oceanográfico de la Armada del Ecuador, Guayaquil, Ecuador, ${ }^{7}$ Petroamazonas EP, Quito, Ecuador, ${ }^{8}$ Universidad \\ Industrial de Santander, Escuela de Geología, Bucaramanga, Columbia
}

Abstract Deciphering the migration pattern of the Esmeraldas submarine Canyon (EC) and its history of cut-and-fill allows constraining the Pliocene-Pleistocene tectonic evolution of the Ecuador-Colombia convergent margin. Swath bathymetry, multichannel seismic reflection, and chronological data show that the EC is a 143-km-long, shelf-incising, river-connected canyon that started incising slope apron deposits in the Manglares fore-arc basin $~ 5.3 \mathrm{Ma}$ ago. The EC inception appears contemporaneous with the subduction of the Carnegie Ridge that is believed to have initiated 5-6 Myr ago and is considered an indirect cause of the EC formation. During its two-stage left-lateral migration, the EC upper-half scoured deep incisions providing evidences for uplift episodes in the Manglares Basin that are correlated with mid-Pliocene and Pleistocene regional tectonic events. Glacioeustatic variations contributed significantly to shape the EC and its upslope tributaries by increasing the rate of canyon incision during rapid sea level falls. Faults, folds, and diapirs have structurally controlled the location of the EC and of its tributary canyons, including the Ancon Canyon, which served as the main spillway of the Manglares Basin prior to be cut from its source $\sim 170 \mathrm{kyr}$ ago by the growth of a fault-related anticline. The margin wedge that hosts the EC is highly unstable as it is cut by active faults and shaken by large subduction earthquakes. Several mass transport deposits have dammed the EC, one of them between $>\sim 65$ and $\sim 37 \mathrm{kyr}$ causing an impoverishment of detrital material in the trench sedimentation and a possible interruption of the paleoseismological record.

\section{Introduction}

Submarine canyon systems are steep-sided valleys that incise continental margins and serve as conduits for particle transport to the deep ocean (Menard, 1955; Normark \& Carlson, 2003; Shepard, 1981). The main cause for the origin of submarine canyons is continental slope erosion by density currents and mass wasting events (Pratson et al., 1994; Shepard, 1981). Many studies have shown that the canyon morphology responds to external forcing such as sea level changes, sediment supply variations, and tectonic processes (Babonneau et al., 2004; Baztan et al., 2005; Huyghe et al., 2004; Laursen \& Normark, 2002). Along convergent margins, tectonic and basement structures deflect the canyon thalweg (Greene et al., 1991; Huyghe et al., 2004; Kukowski et al., 2001; Mountjoy et al., 2009) (Harris \& Whiteway, 2011). The relative convexity or concavity of canyon longitudinal profiles reflects the competing influence of preexisting depositional relief, tectonic deformation, and erosion of the seafloor by sedimentary processes (Covault et al., 2011). Because submarine canyon systems are not purely erosive but are, as well, long-term sedimentary constructions resulting from alternating periods of incision and fill (Amblas et al., 2012; Baztan et al., 2005; Deptuck et al., 2007), investigating preserved nested canyons imaged on seismic data, and analyzing the canyon modern seafloor morphology may help pinpoint the temporal response of canyon systems to seafloor deformation. Therefore, canyons can be used as helpful markers of tectonic deformation to decrypt the recent geomorphic and structural evolution of active margins (Mountjoy et al., 2009). 
In northwestern South America, the Esmeraldas Canyon (EC; Collot et al., 2005) and the Patia and Mira Canyons (Ratzov et al., 2012) cut across the North Ecuador-southwest Colombia convergent margin, immediately north of the Carnegie Ridge collision zone (Figure 1; Gutscher et al., 1999). The canyons traverse the Manglares fore-arc basin (Marcaillou \& Collot, 2008), breach the subduction front and deliver sediment to the Ecuador-Colombia trench turbidite system (Migeon et al., 2017; Ratzov et al., 2012). In contrast with the Patia and Mira Canyons (Figure 1) that are presently river disconnected (Ratzov et al., 2012), the EC is one of the few shelf-incising canyons in the world that remain river-connected during sea level high stands (Harris \& Whiteway, 2011). In this study, we use multibeam bathymetric data, seismic reflection profiles, and a few dredgings and cores collected along the EC and its tributary canyons to (1) explore their morphology and sedimentary architecture and identify loci of active deformation and mass wasting, (2) investigate the temporal evolution of the canyons cut-and-fill structure to constrain the timing of the Late-Neogene deformation of the Manglares Basin and North Ecuadorian coastal region, and (3) analyze the temporal relationship between the Carnegie Ridge subduction and the EC development.

\section{Geological and Structural setting of the EC}

The EC features a major transverse boundary between two structural domains of the Ecuador Colombia margin, where the Nazca Plate underthrusts obliquely $\left(\mathrm{N} 83^{\circ} \mathrm{E}\right)$ the South America forearc at $4.74 \mathrm{~cm} /$ year (Nocquet et al., 2014). Southwest of the canyon, the offshore margin wedge comprises a 20- to 40-km-wide shelf that includes the Esmeraldas Platform (Figure 1) and overhangs a 20- to 30-km-wide, steep outer wedge slope dominated by subduction erosion and mass wasting (Marcaillou et al., 2016; Ratzov et al., 2010; Sage et al., 2006). Northeast of the canyon, the margin wedge reaches $120 \mathrm{~km}$ in width and includes a narrow, 10to $20-\mathrm{km}$-wide shelf and the 80- to 100-km-wide, deep-water Manglares fore-arc basin (Marcaillou \& Collot, 2008). The basin seafloor is deformed by the Ostiones Swell and the NE trending Ancon fault system bordering the Manglares High (Collot et al., 2008; Figure 1). Near the EC mouth, the margin front consists of a narrow accretionary wedge that widens to $\sim 35 \mathrm{~km}$, north of the Patia Canyon (Marcaillou et al., 2008; Mountney \& Westbrook, 1997).

In northern Ecuador, the coastal range, which reaches an altitude of $\sim 300 \mathrm{~m}$ (Reyes, 2013), is cut by the NNW trending Esmeraldas River (Figure 1). In this region, the basement of the margin consists of Cretaceous oceanic terranes (Gossens \& Rose, 1973; Juteau et al., 1977; Reynaud et al., 1999) overlain by a Late CretaceousPaleocene volcano-sedimentary sequence and the thick Cenozoic Borbon sedimentary basin (Cantalamessa et al., 2007; Deniaud, 2000; Di Celma et al., 2010; Evans \& Wittaker, 1982; Jaillard et al., 1995). Gentle NE trending antiforms and east trending faults, including the Canande Fault that separates the Borbon and Manabi Basins (Figure 1), deform the coastal range (Reyes \& Michaud, 2012). Beneath the Manglares Basin, the mafic basement, which has been identified from its 4.0- to 5.0-km/s velocity structure (Agudelo et al., 2009), forms structural highs buried beneath the Ostionies Swell and the Manglares High (Figure 1). Basin deposits that overlay the mafic basement reach $2.5-3 \mathrm{~km}$ in thickness (Collot et al., 2008) and include five major seismic units (A to E) separated by prominent unconformities U1-U4 tentatively dated by correlation with regionally compiled chronostratigraphic charts of the onshore Borbon and Manabi Basins (Marcaillou \& Collot, 2008). In a seismic stratigraphy study, Lopez Ramos (2009) identified eight seismic units deposited during five major eustatic cycles (C1-C5). Five regional unconformities among the eight identified were dated on the basis of the correlation between a seismic stratigraphy onlap chart of the Manglares Basin and a similar chart of the adjacent Tumaco-Borbon Basin constrained by well log and biostratigraphical data. Because the sedimentary environments and ages of Seismic Units A to D can benchmark the temporal evolution of the canyon, their seismic facies, equivalent onshore formations, lithology, and tentative ages are summarized in Figure 2.

The strong tectonic activity of the EC region is supported by (1) the background seismicity (Manchuel et al., 2011), (2) the 1906, 1942, 1958, 1979, and 2016, Mw 7.8 to 8.8 megathrust earthquakes (Kanamori \& McNally, 1982; Mendoza \& Dewey, 1984; Nocquet et al., 2016), (3) the strong seafloor deformation along the Ancon fault system (Collot et al., 2008; Ratzov et al., 2011), (4) the shelf uplift during the Pleistocene (Michaud et al., 2015), and (5) the uplifted Pleistocene marine terraces along the Ecuador northern coast (Pedoja et al., 2006). 


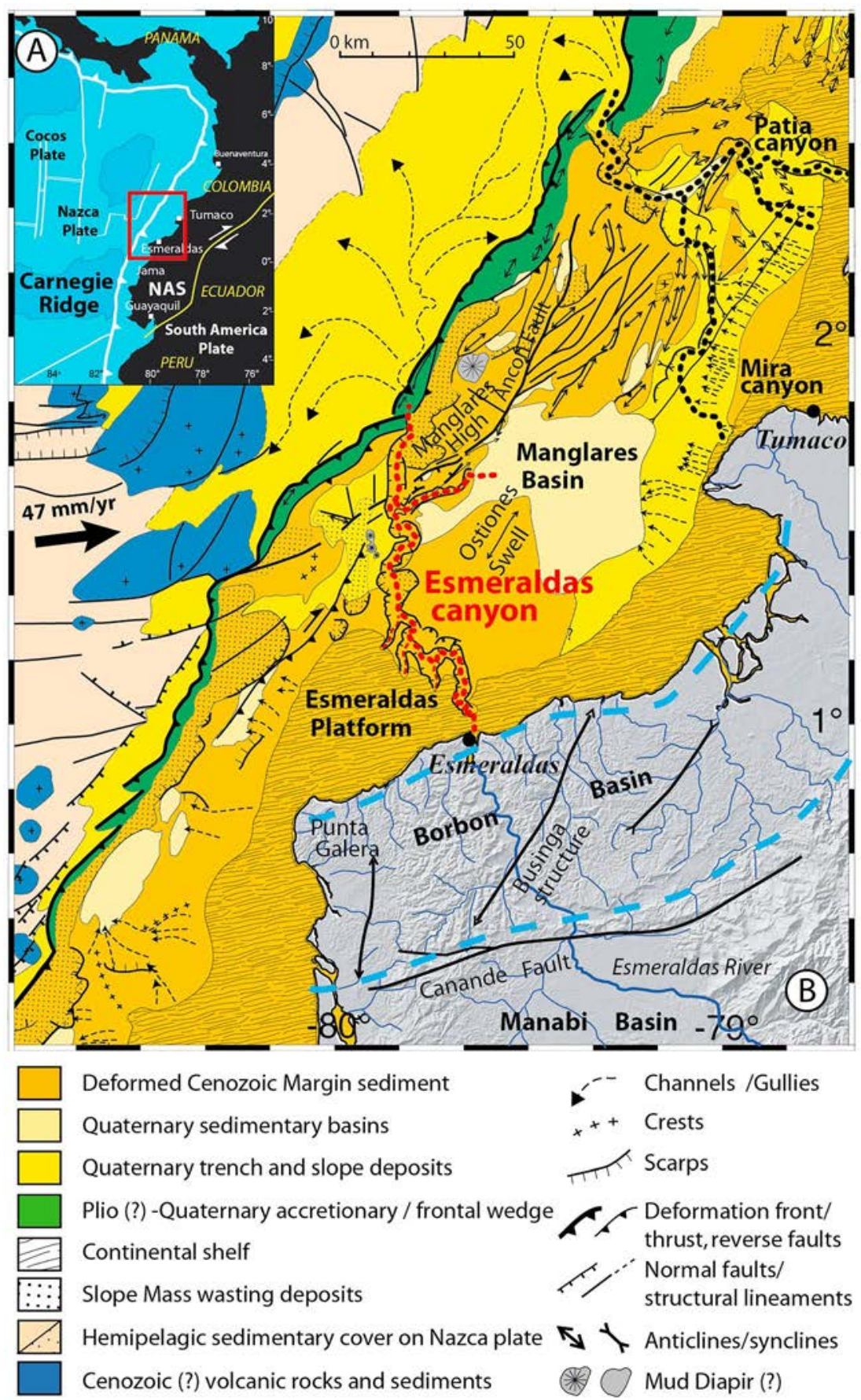

Figure 1. Geological context of the Esmeraldas Canyon; (a) Inset: the red frame is the location of the study area north of the Carnegie Ridge subduction; NAS = North Andean Sliver. (b) Simplified geological and structural setting of the Esmeraldas Canyon modified from Collot et al. (2009). Thick black arrow is relative convergence between Nazca Plate and NAS (Nocquet et al., 2014). Onshore blue dashed line shows estimated limit of the Borbon basin.

\section{Data and Methods}

\subsection{Multibeam Bathymetric Data}

The bathymetric map of the EC (Figure 3) was constructed from swath bathymetry data collected during the 2005 Amadeus and Esmeraldas cruises (RV L'Atalante), using a SIMRAD EM12D multibeam system (13 $\mathrm{kHz}, 162$ beams) (Collot et al., 2005). This data set was completed by higher-resolution multibeam swath 


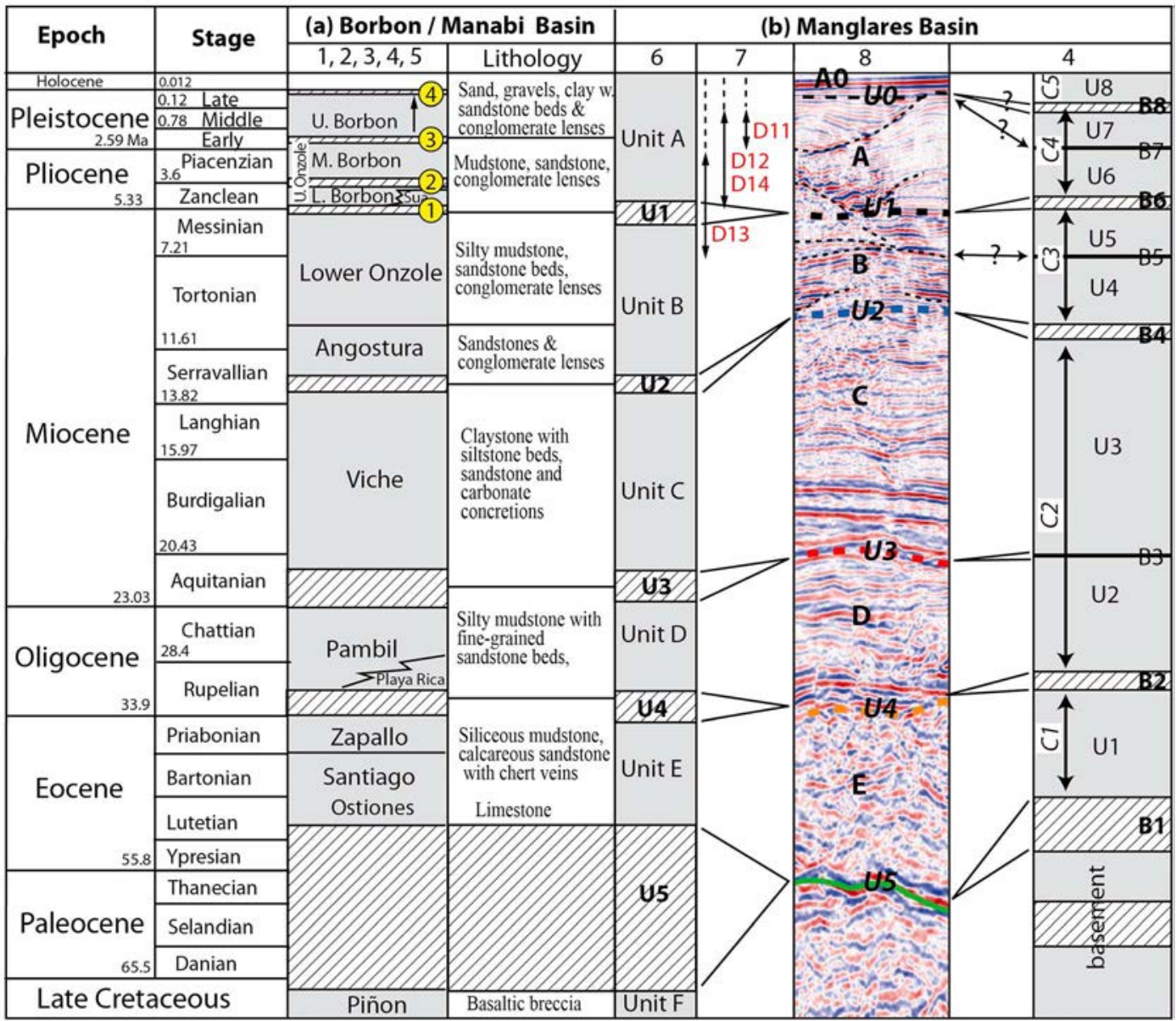

Figure 2. Onshore-offshore chronostratigraphic correlations; (a) composite chronostratigraphic chart of the Borbón and Manabi Basins modified from $1=$ Deniaud (2000), 2 = Ordonez et al. (2006), 3 = Evans and Wittaker (1982), 4 = Lopez Ramos (2009), and 5 = Reyes (2013); (b) correlation between the Borbon and the Manglares Basins after $6=$ Marcaillou and Collot (2008): Seismic Units A to E and U1 to U5 unconformities; $4=$ Lopez Ramos (2009): Seismic Units U1 to U8 and $\mathrm{B} 1$ to $\mathrm{B} 8$ unconformities, and $\mathrm{C} 1$ to $\mathrm{C} 5$ are eustatic cycles; $7=$ this work: double arrows with red labels represent the age ranges of rock samples dredged at Sites D11 to D14 along the Esmeraldas Canyon (Table 1); 8 = this work: seismic facies of Units A0 to E with unconformities U0 to U5; Yellow circled numbers = proposed correlation between Esmeraldas Canyon incision Phases 1 to 4 and onshore unconformities; simple vertical arrow denotes the most recent uplift of the coastal range (Pedoja et al., 2006; Reyes, 2013).

data collected on the upper canyon segment using SIMRAD EM122 (12 kHz, 288 beams) and EM710 (100 $\mathrm{kHz}, 256$ beams) echosounders during the 2012 Atacames cruise (RV L'Atalante), and an EM302 multibeam system operated by INOCAR (RV Orion) in 2013. The RV L'Atalante bathymetric data were processed using the CARAIBES software (IFREMER). The full data set allowed constructing a uniform digital elevation model with a 150-m grid spacing, using the nearest neighbor algorithm of the GMT software (Wessel \& Smith, 1998).

\subsection{Seismic Reflection}

Multichannel seismic reflection (MCS) data were acquired during the 2005 Amadeus and 2009 Scan cruises. Scan MCS data were recorded using a 4000-ci (65.5 L), 20- to 80-Hz frequency air gun seismic source, and a 640-channel, 8-km-long streamer. Shots were fired every $25 \mathrm{~m}$, providing a 160 -fold coverage. Scan MCS data were processed by SINOPEC (China Petroleum and Chemical Corporation) for PetroEcuador through classical steps (Yilmaz, 2001) including multiple elimination, spherical divergence compensation, predictive deconvolution in the Tau-P domain, prestack noise attenuation, stacking, and prestack time migration. Amadeus MCS data were collected using a 150-ci air guns source set up in Generator Injector mode, combined with a 300-m-long, six-channel streamer. Shots were fired at 18.5 $\mathrm{km} / \mathrm{h}$ (10 knots) every $25 \mathrm{~m}$ providing a threefold coverage. Amadeus seismic lines were processed 


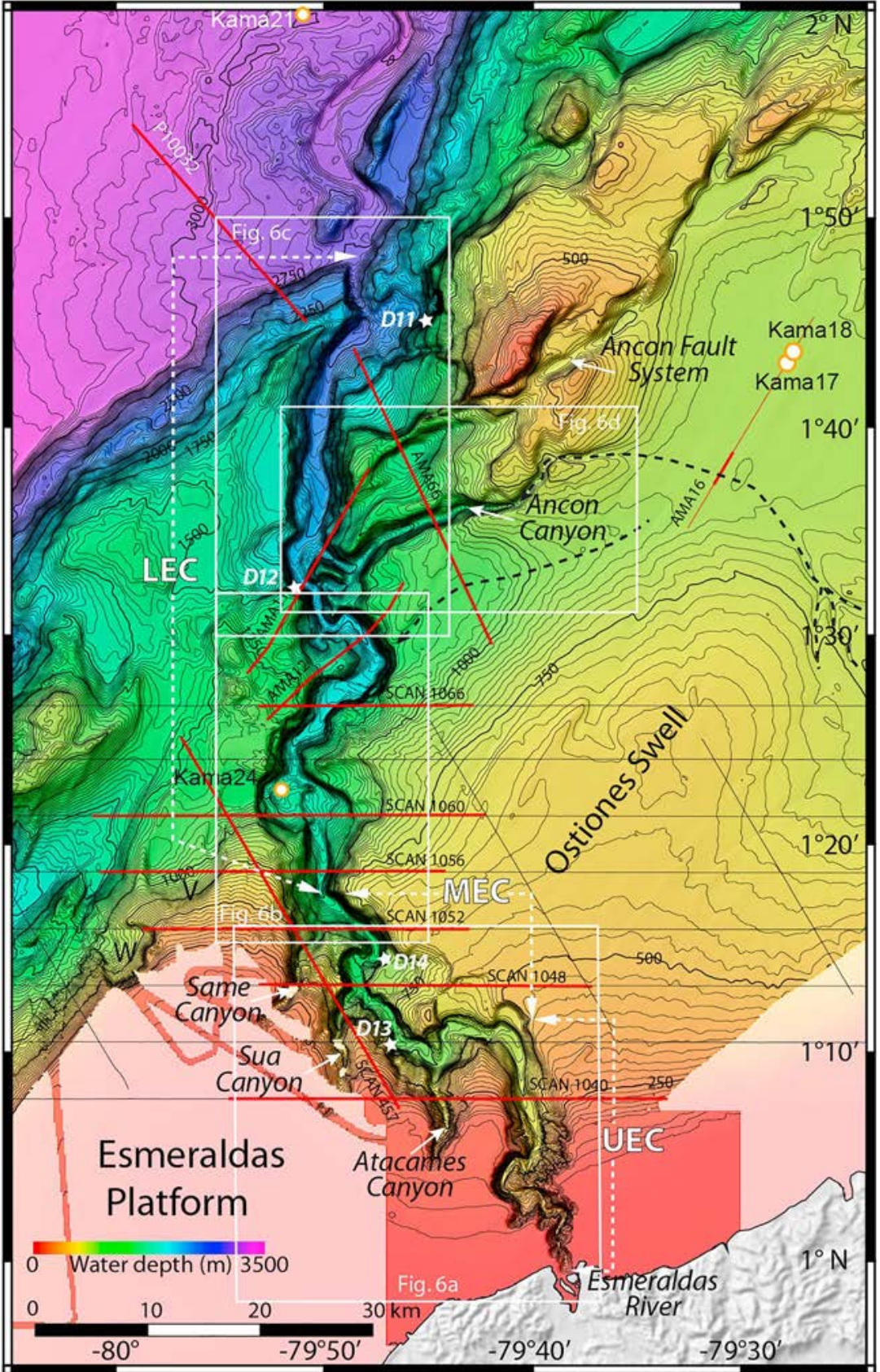

Figure 3. Multibeam bathymetric map of the Esmeraldas Canyon and its tributary canyons; contour interval is $25 \mathrm{~m}$. Solid red lines are multichannel seismic reflection lines shown in this study. White dots with "Kama" show the location of sediment cores. White stars are dredging Sites D11-D14. Black dashed lines show paleosedimentary transport systems from the Manglares Basin. White frames are the location of Figures $6 \mathrm{a}$ to $6 \mathrm{~d}$. UEC $=$ Upper Esmeraldas Canyon; MEC $=$ Middle Esmeraldas Canyon; LEC = Lower Esmeraldas Canyon; V and W are slump scars.

with Seismic Unix (Center of Wave Phenomena, Colorado School of Mines) for band-pass filtering, spherical divergence correction (water velocity) - NMO velocity analysis and correction, threefold stack and constant water velocity time migration. The seismic data are used to identify Regional Seismic Units $\mathrm{A}$ to $\mathrm{E}$ and characterize the variability of the sedimentary and structural environment of the EC. Lower, middle, and upper canyon fill series were interpreted along individual seismic lines with no a priori genetic relationship between each series along the canyons. 


\subsection{Dredges and Cores Data}

Rocks were dredged at four sites (Figure 3) along short depth intervals of the canyon walls. Dredging sites were relocalized using the bathymetry data, dredge-cable length, and ship location. However, the global characters of the dredging technique make it difficult to pinpoint the provenance of the samples on the seabed. The samples were dated using microfauna (Table 1). Four 3.75 to 8.28-m-long sediment piston cores recovered (Figure 3) using a Kullenberg-type corer were analyzed and dated to calculate Pleistocene sedimentation rates (Gastaud, 2010; Migeon et al., 2017).

\section{Results}

\subsection{General EC Morphology}

The EC extends over a length of $\sim 143 \mathrm{~km}$ along its course from the mouth of the Esmeraldas River, down to the Colombia trench, where the canyon sharply cuts the subduction front at a depth of $\sim 2,750 \mathrm{~m}$ (Figure 3; Silva Chamorro, 2007). The EC valley is $2.5-12 \mathrm{~km}$ wide, locally more than $1,000 \mathrm{~m}$ deep with respect to the surrounding seafloor. Its thalweg exhibits an overall sinuosity of 1.53 and thus presents a meandering pattern (Leopold \& Wolman, 1957). It is $0.25-1.4 \mathrm{~km}$ wide (Figure 4 ) and flanked by $20-30^{\circ}$ steep walls reaching in places more than $40^{\circ}$ (Figure 5). From its head region, the canyon incises the narrow shelf and follows the junction between the Esmeraldas Platform and the Ostiones Swell, prior to winding through the lower margin wedge. The overall NS trending course of the canyon is diverted twice allowing defining three distinct canyon segments (Figure 3): (a) the 42-km-long, Upper Esmeraldas Canyon (UEC) trends NS; (b) the 33km-long, Middle-slope Esmeraldas Canyon (MEC) trends predominantly W to NW; and (c) the 68-km-long, Lower-slope Esmeraldas Canyon (LEC), which course returns roughly to its NS initial direction. Four tributary canyons join the main canyon. Upslope, the NS trending Atacames, Sua, and Same Canyons incise the edge of the Esmeraldas Platform and the upper margin slope (Michaud et al., 2015). Further down slope, the ENE trending Ancon Canyon (AC) originating from the Manglares Basin incises the lower margin wedge.

\subsection{The UEC}

\subsubsection{Morphology}

The short UEC trends perpendicular to the upper margin slope. It is connected with the mouth of the Esmeraldas River in a water depth of $20 \mathrm{~m}$ (Figure 6a), while downstream, the UEC breaches transversally the shelf along deeply incised meanders forming a winding shelf valley with up to $30-40^{\circ}$ steep walls (Figure 5), prior to incising the margin upper slope to $\sim 800 \mathrm{~m}$ of water depth. Bathymetric Cross Sections 1 and 2 of UEC (Figure 4) generated from the multibeam bathymetric data grid reveal V-shaped, asymmetric sections that incise the shelf by up to $500 \mathrm{~m}$. Downstream, Cross Section 3 reveals a U-shaped thalweg across the upper margin slope, and narrow, slant terrace tA (Figure 6a).

\subsubsection{Seismic Structure}

Seismic Units A to E and bounding unconformities initially interpreted by Marcaillou and Collot (2008) are identified on Line SCAN-1040 (Figure 7) together with new Seismic Unit A0 and its basal unconformity U0. The line shows that the UEC together with the Atacames and Sua Canyons settled across the structural transition from the thickly sediment-filled Manglares Basin to the thinner sedimentary cover of the Esmeraldas Platform. The transition is marked by the basement top (U5) that shallows from a 3.0-s TWTT (two-way travel time) depth east of the UEC to less than 1.5-s TWTT deep, west of the Sua Canyon. Two structural features accommodate the lateral transition: (1) a basement fault network that deformed Unit $\mathrm{E}$ and gently folded Units D and C beneath the Atacames Canyon and UEC, where angular unconformity U2 truncates Unit C reflectors, and (2) diapiric intrusions interpreted on the basis of the subvertical, nonreflective core of Unit $\mathrm{C}$ anticline structures between the UEC and Sua Canyon. The UEC incised Units A and B, likely reaching the top of Unit C. Unit C exhibits relatively uniform and well-bedded seismic facies, while Unit B consists of stacks of wedge- and lens-shaped stratified bodies returning low angle, either weak or strong, and by places chaotic reflections when channelized. This remarkable contrast reveals a major change in the sedimentary environment after the formation of unconformity U2. Slant terrace tA (Figure 7) exhibits a reflectivity sequence similar to that of the adjacent Unit A and top of Unit B, from which the sequence is offset downward by $\sim 0.25$-s TWTT, and it is thus thought to be an elongated slump block. Similar failures affect the opposite flank of the canyon (Figure 7). Further south on the shelf, a curved linear depression following the canyon eastern rim (LD in Figure 6a) mimics the shape of the meanders, suggesting an area prone to block slumping. 
Table 1

Lithology and Age of Samples Dredged From the Esmeraldas Canyon During the Amadeus Cruise

\begin{tabular}{|c|c|c|c|c|c|}
\hline $\begin{array}{l}\text { Dredge } \\
\mathrm{N}^{\circ}\end{array}$ & Sample & & $\begin{array}{l}\text { Water depth } \\
(\mathrm{m})\end{array}$ & Description & Age \\
\hline \multirow[t]{4}{*}{ DAMA11 } & D11-E1 & & \multirow[t]{4}{*}{$1,500-2,250$} & $\begin{array}{l}\text { Dark gray siltstone with levels of fine sands, bioturbations with } \\
\text { pellets }\end{array}$ & Early to Middle Pleistocene, ${ }^{*}$ B and ${ }^{*} \mathrm{P}$ \\
\hline & D11-E3 & & & Gray siltstone with bioturbations & Lower Early Pleistocene, ${ }^{*} \mathrm{~B}$ and ${ }^{*} \mathrm{P}$ \\
\hline & D11-E6 & & & Yellowish siltstone with bioturbations & Early Pleistocene, ${ }^{*} \mathrm{~B}$ and ${ }^{*} \mathrm{P}$ \\
\hline & D11-E11 & & & Siltstone & Early Pleistocene, ${ }^{*} \mathrm{~B}$ and ${ }^{*} \mathrm{P}$ \\
\hline \multirow[t]{6}{*}{ DAMA12 } & & & \multirow[t]{6}{*}{$1,850-2,170$} & & \\
\hline & D12-E4 & & & Siltstone & Lower Early Pleistocene, ${ }^{*} \mathrm{~B}$ and ${ }^{*} \mathrm{P}$ \\
\hline & D12-E6 & & & Siltstone & Pliocene to Upper Early Pleistocene, ${ }^{*} \mathrm{P}$ \\
\hline & D12-E8 & & & Siltstone & $\begin{array}{l}\text { Upper Early to Middle Pleistocene }{ }^{*} \mathrm{~B},{ }_{\mathrm{R}}^{*} \mathrm{P} \text {, and } \\
\end{array}$ \\
\hline & D12-E9 & & & Siltstone & $\begin{array}{l}\text { Late Pliocene to Middle Pleistocene, }{ }^{*} \mathrm{~B},{ }^{*} \mathrm{P} \text {, } \\
\text { and }{ }^{*} \mathrm{R}\end{array}$ \\
\hline & $\begin{array}{l}\text { D12-E14, } \\
\text { E18 }\end{array}$ & E16, & & Siltstone & Pliocene to Middle Pleistocene, ${ }^{*} \mathrm{P}$ \\
\hline \multirow[t]{4}{*}{ DAMA13 } & D13-E1 & & \multirow[t]{4}{*}{$850-1,050$} & Gray siltstone with lenses of sandstone and bioturbation & $\begin{array}{l}\text { Late Miocene to Late Early Pliocene, }{ }^{*} \mathrm{~B} \text { and } \\
{ }_{\mathrm{P}}\end{array}$ \\
\hline & D13-E2 & & & Siltstone with lenses of laminated sandstone & Upper Early Pliocene, ${ }^{*} \mathrm{~B}$ and ${ }^{*} \mathrm{P}$ \\
\hline & D13-E4 & & & Poorly compacted Silt with fractures & Pliocene, ${ }^{*} \mathrm{~B}$ and ${ }^{*} \mathrm{P}$ \\
\hline & D13-E6 & & & Mudstone & Upper Early Pliocene, ${ }^{*} \mathrm{~B}$ and ${ }^{*} \mathrm{P}$ \\
\hline \multirow[t]{3}{*}{ DAMA14 } & D14-E1 & & \multirow[t]{3}{*}{$900-1,250$} & Olive gray siltstone with bioturbation & Upper Early to Middle Pleistocene \\
\hline & D14-E3 & & & Siltstone with pellet facies & Early to Middle Pleistocene, ${ }^{*} \mathrm{~B},{ }^{*} \mathrm{P}$, and ${ }^{*} \mathrm{R}$ \\
\hline & D14-E4 & & & Poorly compacted mudstone & Pliocene to Early Pleistocene ${ }^{*} \mathrm{~B}$ and ${ }^{*} \mathrm{P}$ \\
\hline
\end{tabular}

Note. Ages were estimated from determination of $* \mathrm{~B}=$ benthic foraminifera; ${ }^{*} \mathrm{P}=$ pelagic foraminifera; $* \mathrm{R}=$ radiolarian, ${ }^{*} \mathrm{D}=$ diatom; location of dredging sites in Figure 3.

\subsection{The Middle Esmeraldas Canyon (MEC)}

\subsubsection{Morphology of the MEC and Its Tributary Canyons}

The MEC trends nearly parallel to the regional bathymetric contours and shows a sinuous course. Two linear MEC stretches trend NW for $\sim 8 \mathrm{~km}$ (Figures 6a and 6b). Cross Sections 4-6 (Figure 4) show that the MEC is U-shaped and asymmetric, showing a steep (30-40 $)$ southern flank (Figure 5), and a northern flank indented by terraces $\mathrm{tB}, \mathrm{tC}$, and $\mathrm{tD}$ that are ensconced within arcuate, south to west facing gentle scarps (Figure 6a). Mound $\mathrm{M}$ is a higher isolated flat-topped relief between terraces $\mathrm{tC}$ and $\mathrm{tD}$ that features an outlier preserved from the canyon erosion. On bathymetric Cross Section 7 (Figure 4) the canyon is deep and V shaped, suggesting that near the northern end of the MEC (Figure 6b), the canyon actively incises the upper margin slope. The Atacames, Sua, and Same tributary canyons are V shaped (Figure 5) and flanked by slant terraces. Their mouths are truncated and are slightly overhanging the MEC thalweg, indicating that the tributary canyons may be presently less active than the MEC.

\subsubsection{Seismic Structure of the MEC and Its Tributary Canyons}

The structural and sedimentary environments of the MEC and its tributary canyons, as well as elements of their paleocourse, are interpreted from Lines SCAN-1040, 1048, 1052, and 457. Along Line SCAN-1048 (Figure 8), unconformity U1, which truncates Unit B reflectors, down cuts more severely Unit B across two depressions interpreted as paleoincisions: Incision 2 beneath terrace tD (Common Depth Point [CDP] 8700-9200, Figure 8), and Incision 1 partially beneath terraces tC (CDP 9300-9800, Figure 8). The latter is bounded eastward at CDP 9800 by a buried scarp interpreted as the easternmost bound of the paleo-MEC. A buried levee complex inferred on the eastern rim of Incision 1 ( $V c$ in Figure 8), supports the idea that the paleo canyon/channel was active during Unit A early sedimentation stage.

Unit A shows a chaotic lower sedimentary series $(L a)$ within Incision 1, suggesting that mass transport deposits (MTDs) laid down in the paleocanyon. Above the MTD, thinly stratified middle series Ma pinches out away from the paleocanyon axis, and upper series $U a$ is more draping. Both $M a$ and $U a$ series might represent confined inner levees (e.g., Babonneau et al., 2004). Similarly, beneath terrace tD, Unit A consists of wedge-shaped, low-amplitude, and thinly layered reflectors supporting canyon inner levees confined into Incision 2. Therefore, the arcuate seafloor morphology of terraces tC and tD (Figure 6a) combined with the 


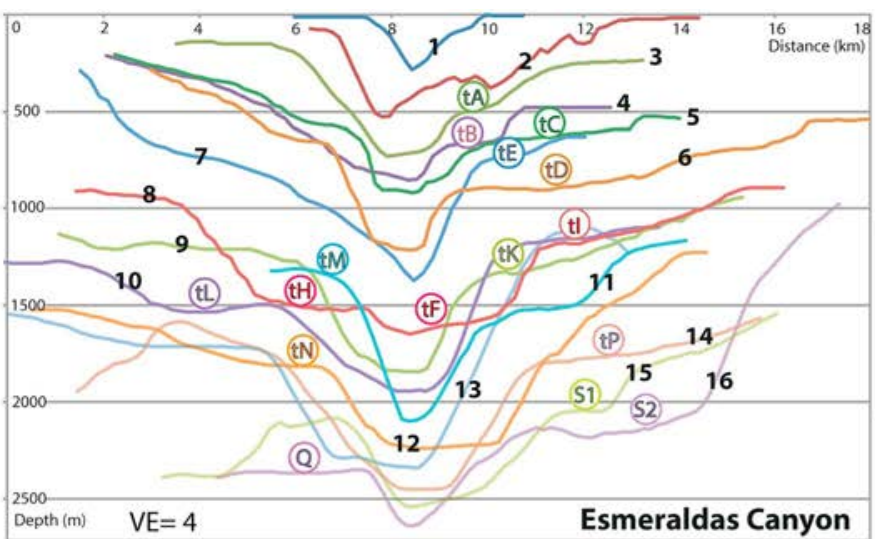

(A)

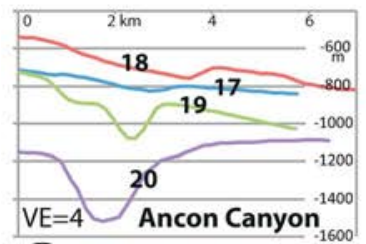

(B)
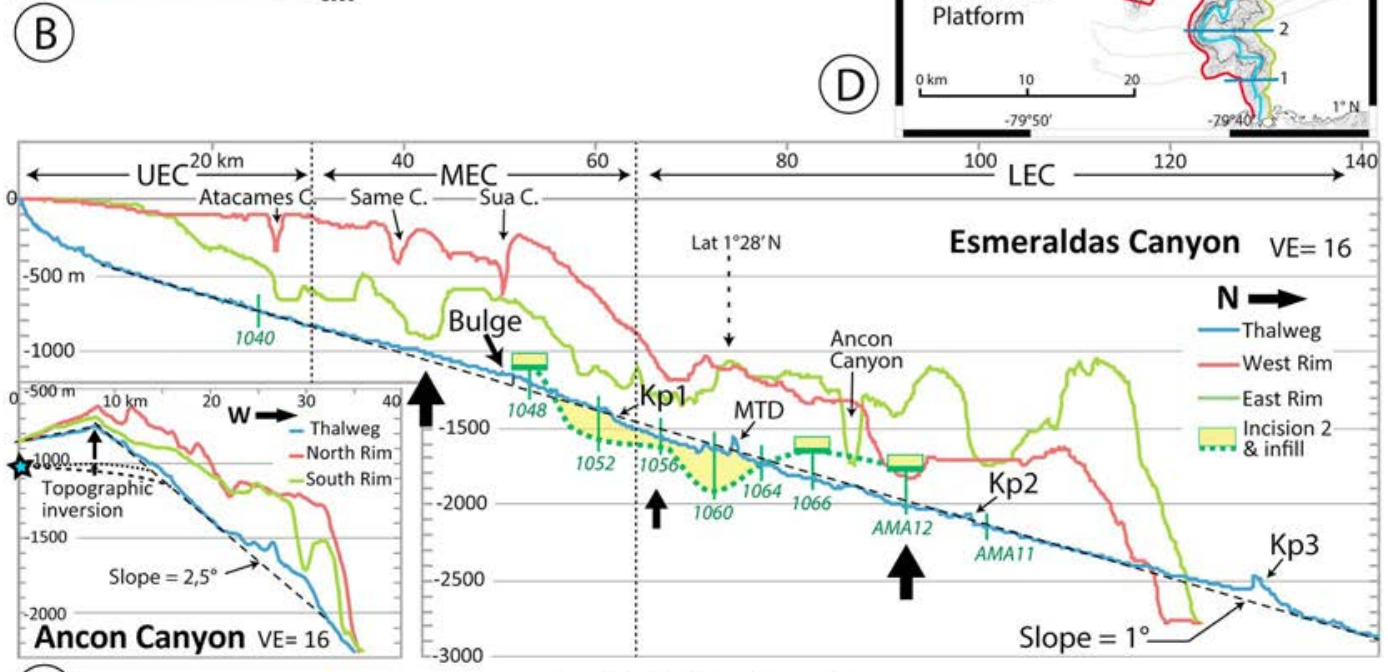

(C)

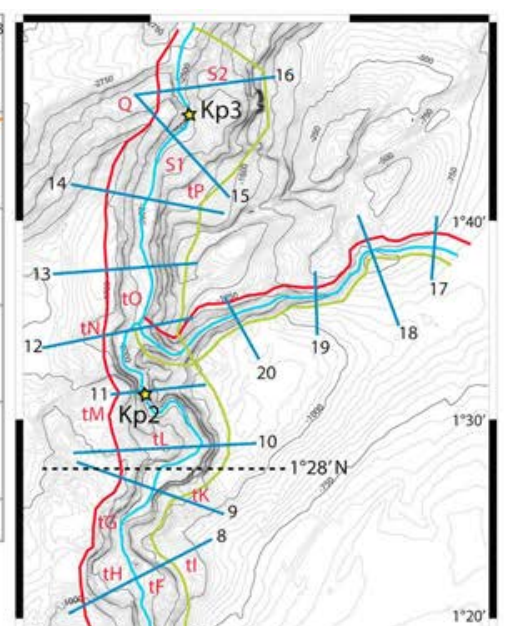

Longitudinal depth profiles

Figure 4. Esmeraldas and Ancon Canyons bathymetric sections; (a) Esmeraldas Canyon depth Cross Sections 1 to 16. (b) Ancon Canyon depth Cross Sections 17 to 20. VE = vertical exaggeration; (c) Longitudinal depth profiles of the Esmeraldas and Ancon Canyons; UEC, MEC, and LEC as in Figure 3; Esmeraldas Canyon: MTD = mass transport deposit; note the variable depth of Incision 2 and sediment infill indicating potential uplift variations along the canyon valley (vertical black arrows); Ancon Canyon: blue star is the westward projection of the 1,000-m depth of the buried canyon bottom on Line AMA16 (Figure 5); (d) Location map of depth cross sections and longitudinal profiles; $\mathrm{Kp}=$ knick points.

stratigraphic series that fill their underlying paleoincisions (Figure 8), suggest that canyon paleomeanders underlay the terraces.

At the junction between the MEC and the Same Canyon, Line SCAN-1052 (Figure 9) reveals primary elements of the canyon setting up and evolution. A tight fold intruded by a diapiric structure deforms Unit D beneath the canyon eastern flank. The canyon, which truncated the fold western flank during Incision 2 (Figure 9), was filled by (1) chaotic lower series $L b$ interpreted as including a MTD unconformably overlain (Incision 3) by (2) down lapping, low-angle highly reflective series $M b$, which is unconformably covered (Incision $3^{\prime}$ ) by (3) poorly reflective, down lapping series $U b$. The latter is presently dissected (Incision 4) 


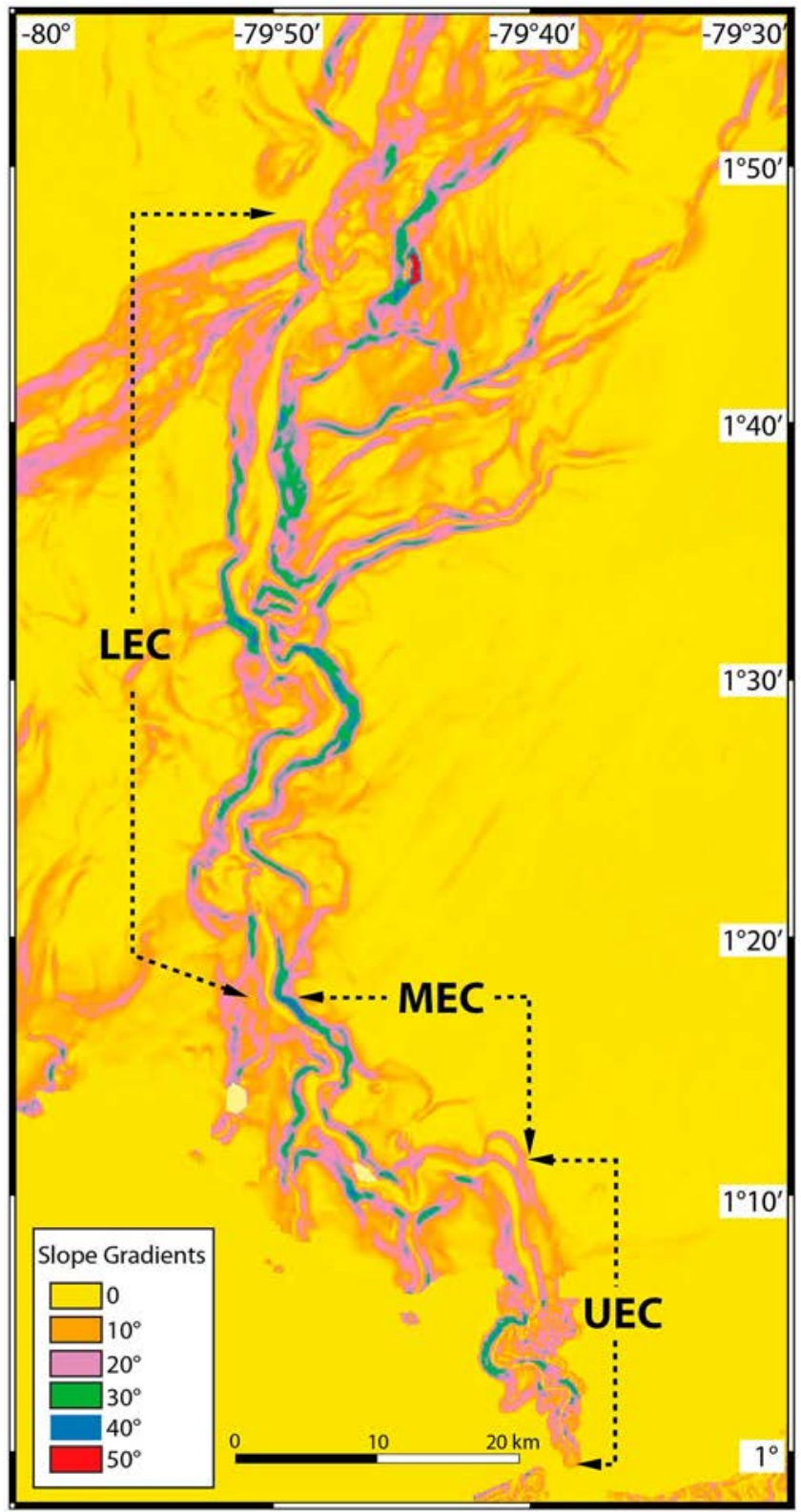

Figure 5. Seafloor slope map $\left({ }^{\circ}\right)$ of the Esmeraldas Canyon; UEC, MEC and LEC as in Figure 3.

by the Same and Esmeraldas Canyons. The seismic configuration of series $\mathrm{Mb}$ an $\mathrm{Ub}$ indicates downslope deposition, which reflects either localized progradational wedges or imbricate confined levees.

Line SCAN-457 (Figure 10) reveals critical elements to understanding the origin of the Same and Sua tributary canyons. Between CDP 1050-1350, a sediment-filled, flat-bottomed, 0.5-s TWTT-deep paleoincision is interpreted beneath the Same Canyon. Interestingly, this erosional feature is not observed $4 \mathrm{~km}$ upslope beneath the Same Canyon on Line SCAN-1048. On Line SCAN-457, the incision sediment fill associated with the Same Canyon consists of seismic series similar in both vertical succession and seismic facies with $\mathrm{Lb}, \mathrm{Mb}$, and $\mathrm{Ub}$ series described downslope across the MEC on Line SCAN-1052. These close similarities allow inferring that a gravity-driven event that sourced immediately downslope of Line SCAN1048 excavated the slope down to the Same Canyon junction with the MEC (Figure 6a), and plugged the MEC with MTD Lb.

On Line SCAN-1040, near the edge of the Esmeraldas Platform, the Sua Canyon incises Unit A along the axis of a syncline (Figure 7) that is also detected further downslope along Line SCAN-457 (Figure 10). On this 

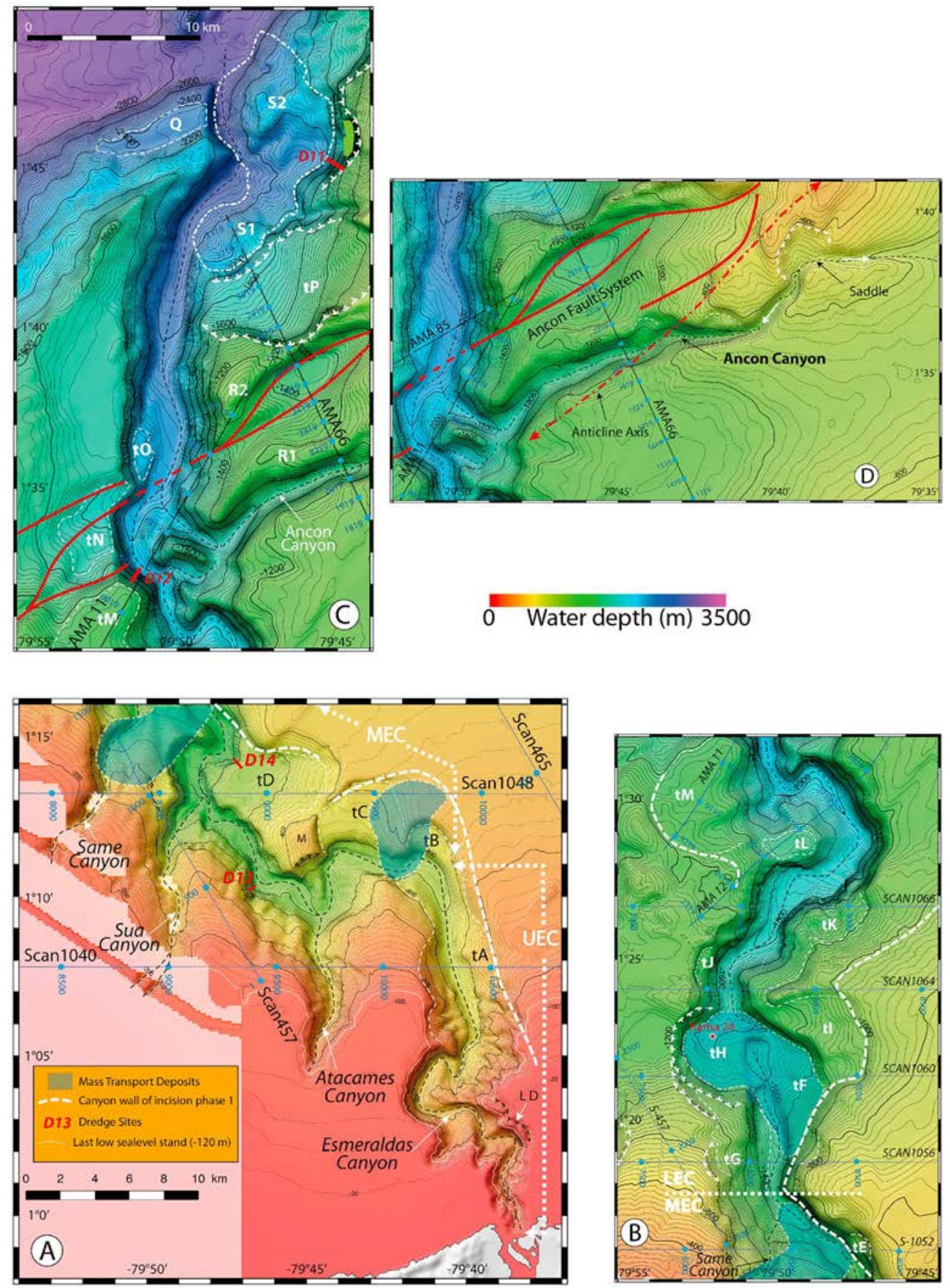

Figure 6. Detailed bathymetric maps of the Esmeraldas and the Ancon Canyon. Contour interval is $20 \mathrm{~m}$. Location of Boxes A, B, C, and D in Figure 3; UEC, MEC, LEC as in Figure 3; Kama $24=$ sediment core. tA -tO are terraces; LD in Figure 6a is linear depression; Q in Figure 6c is flat floor piggy-back basin, and S1 and S2 are mass transport deposits; white arrows in Figure 6d show particle flow direction.

line, beneath the Sua Canyon, Unit B deepest reflectors lap onto U2 unconformity on both flanks of the syncline, so that the unit fills locally a structural paleovalley. Similarly on Line SCAN-1040 (Figure 7), the Atacames Canyon incises Units A and B along a syncline axis.

\subsubsection{Dredging Along the MEC Flanks}

Dredging at site D13 along the steep MEC western flank (Figure 6a) collected siltstone with lenses of laminated sandstone as well as poorly compacted mudstone. The siltstone was dredged from an outcrop of Unit $B$ as indicated by seismic interpretation, and the dredged samples possibly include bits from overlying Unit A. 

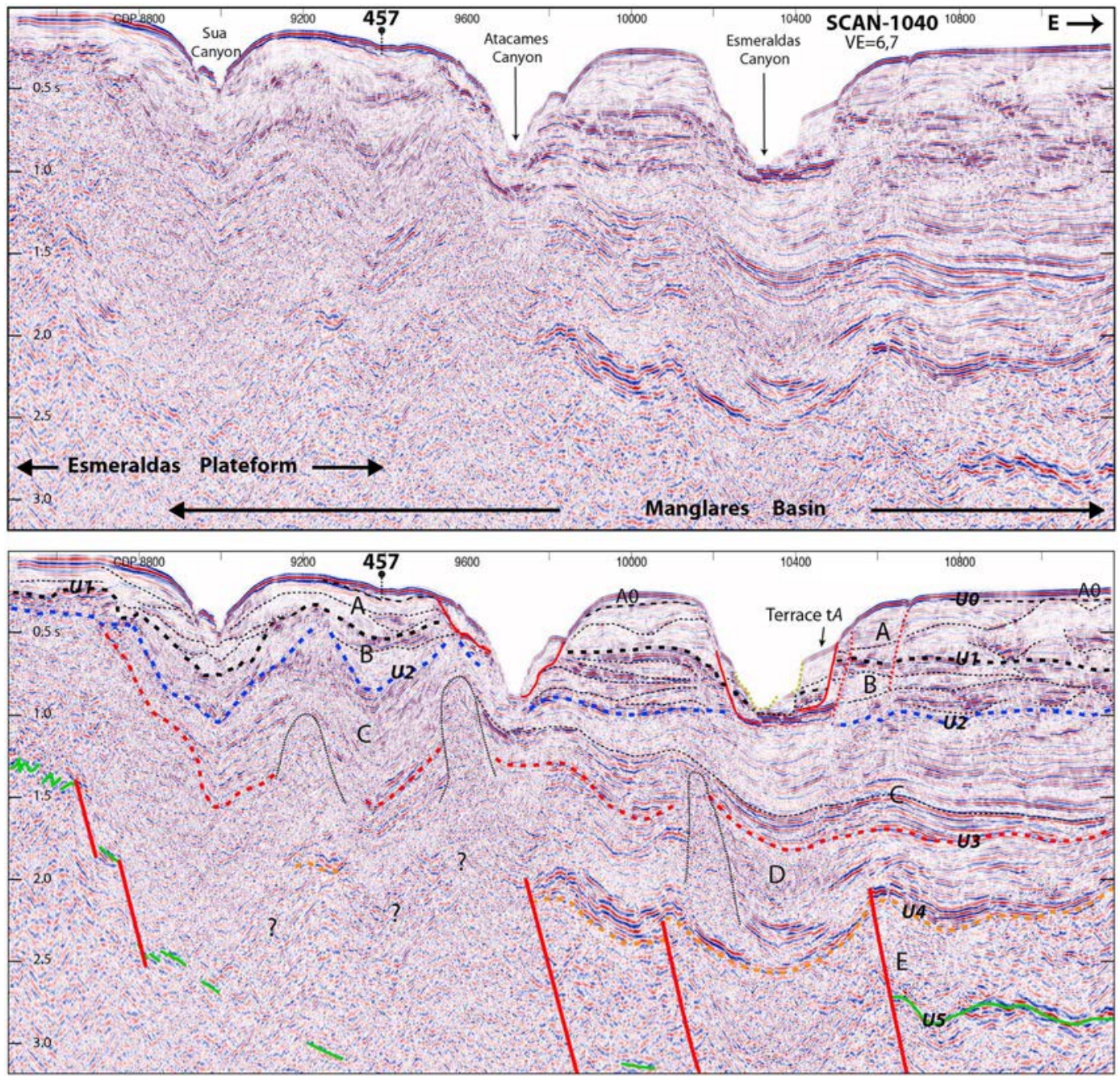

Figure 7. Seismic Reflection Line SCAN-1040 shows the structural transition between the Manglares Basin and the Esmeraldas Platform across the Esmeraldas, Atacames and Sua Canyons; location in Figures 3 and 6a; 457 is Cross Line SCAN-457; capital letters A to E are regional Seismic units, and U0-U5 are unconformities; CDP are Common Depth Points; VE is vertical exaggeration in the water column; deep faults in red deform the thick sedimentary basin beneath the canyons, and diapiric structures intrude Unit $\mathrm{C}$ forming anti/synclines beneath the shelf; note the drastic change in seismic facies between Unit $\mathrm{C}$ basin floor deposits and Unit B slope apron in the Manglares Basin.

Some D13 samples are dated Late Miocene to late early Pliocene, and others late Pliocene-early Pleistocene (Table 1).

Dredge D14 along the steep northwestern flank of terrace tD (Figure 6a) recovered bioturbated siltstone, poorly compacted mudstone and black siltstone rich in organic matter. These rocks were dredged from an outcrop of Unit A, interpreted as confined levees on Line SCAN-1048 (Figure 8), and dated Pliocene to Middle Pleistocene (Table 1).

\subsection{The LEC}

\subsubsection{Morphology of the LEC}

Along its path to the trench, the LEC incises the lower margin slope, obliquely to the NE trending regional bathymetric contours. The canyon shows a few bends and meanders, overhanging terraces and short linear stretches trending dominantly NS, NW, and NE (Figure 3). The longitudinal depth profiles of the western and eastern rim of the EC exhibit clear differences (Figure 4c). While the depth profile of the western rim is shallower than that of the eastern rim on the upper margin slope, they reach a similar depth near latitude $1^{\circ} 28^{\prime} \mathrm{N}$. From this point downslope, the depth difference of the profiles is reversed with a shallower eastern 

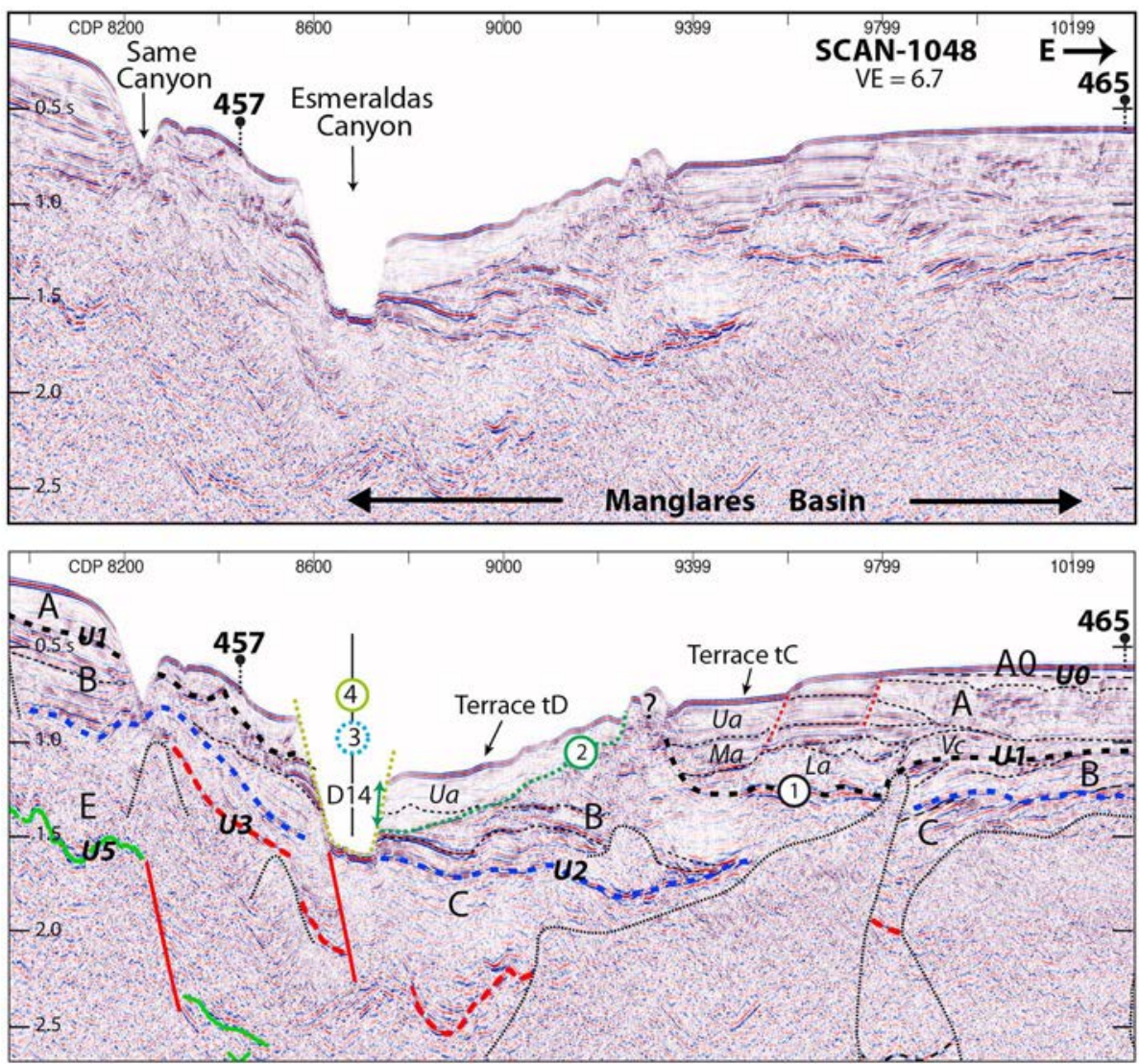

Figure 8. Seismic Reflection Line SCAN-1048 shows evidence for Canyon Incision 1 beneath terrace tC, and Incision 2 beneath terrace tD; axial Incision 4; Incision 3 has not been observed; location in Figures 3 and 6a; seismic units, unconformities, VE and CDP as in Figure 7; D14 is projection of rock dredging (Table 1); 457 and 465 are Cross Lines SCAN; continuity between the base of Incision 1 and U1 suggests synchronicity. La, Ma, and Ua are lower, middle, and upper series of Unit A; Vc is buried levee complex; thin dotted lines limit fuzzy zones that suggest diapirs west of the Esmeraldas Canyon and possibly seismic artifacts or gas east of it; note that the reflective section of Unit B forms a monocline across the canyons indicating uplift of the Esmeraldas Platform.

rim that also exhibits a more complex morphological pattern. These differences point to various tectonic and sedimentary influences as discussed further below.

At latitude $1^{\circ} 22^{\prime} \mathrm{N}$, the LEC valley enlarges up to $\sim 11 \mathrm{~km}$ and hosts several nested terraces (Cross Section 8 , Figures 4 and $6 \mathrm{~b}$ ). At latitude $1^{\circ} 30^{\prime} \mathrm{N}$, it tightens and draws a large meander along which the LEC eroded the Manglares Basin by up to $730 \mathrm{~m}$ (Cross Section 10, Figure 4), carving a steep outer flank (Figure 5). In map view, the large meander does not exhibit a smooth bend but it does consist of a series of short linear stretches at $90^{\circ}$ angles, trending NE or NW (Figure $6 \mathrm{~b}$ ), thus suggesting a structural control. The terraces show a variety of shape, morphology and altitude relative to the canyon thalweg pointing to diverse origins and evolution. Few have a subhorizontal seafloor (e.g., tL and tO), whereas nearly all (e.g., tG and tK) are slant (Figure 6). Terrace tH that stands near the canyon bottom, dips north, and shows a rough morphology (Figure 6b). Cross Sections 9 and 10 (Figure 4) reveal slant terrace tK perched on the canyon eastern flank and horizontal terrace tL that is bypassed by the large canyon meander. Horizontal, terrace tM (Figures $6 \mathrm{~b}$ and $6 \mathrm{c}$ ) is ensconced to the SW in a 100- to 200-m-high semicircular scarp, whereas to the NW, it overhangs the lower margin by $\sim 300 \mathrm{~m}$, suggesting that its northwestern flank was tectonically deformed by the Ancon fault system.

From the confluence with the AC northward, the LEC trends roughly NS (Figure 6c) crossing a structurally complex lower margin wedge. The LEC is characterized by an entrenchment achieving $\sim 1,200 \mathrm{~m}$ in height along its eastern flank (Cross Section 13, Figure 4), with 20-30 slopes (Figure 5). Bathymetric Cross Sections 12 to 15 (Figure 4a) reveal a U-shaped, 2-km-wide thalweg that contrasts with the V-shaped and $\sim 0.5-\mathrm{km}$ wide thalweg in Cross Sections 11 and 16 thus potentially reflecting effects of local tectonics. At the AC confluence, the LEC shows sharp changes of course between 2- and 4-km long, linear stretches trending 


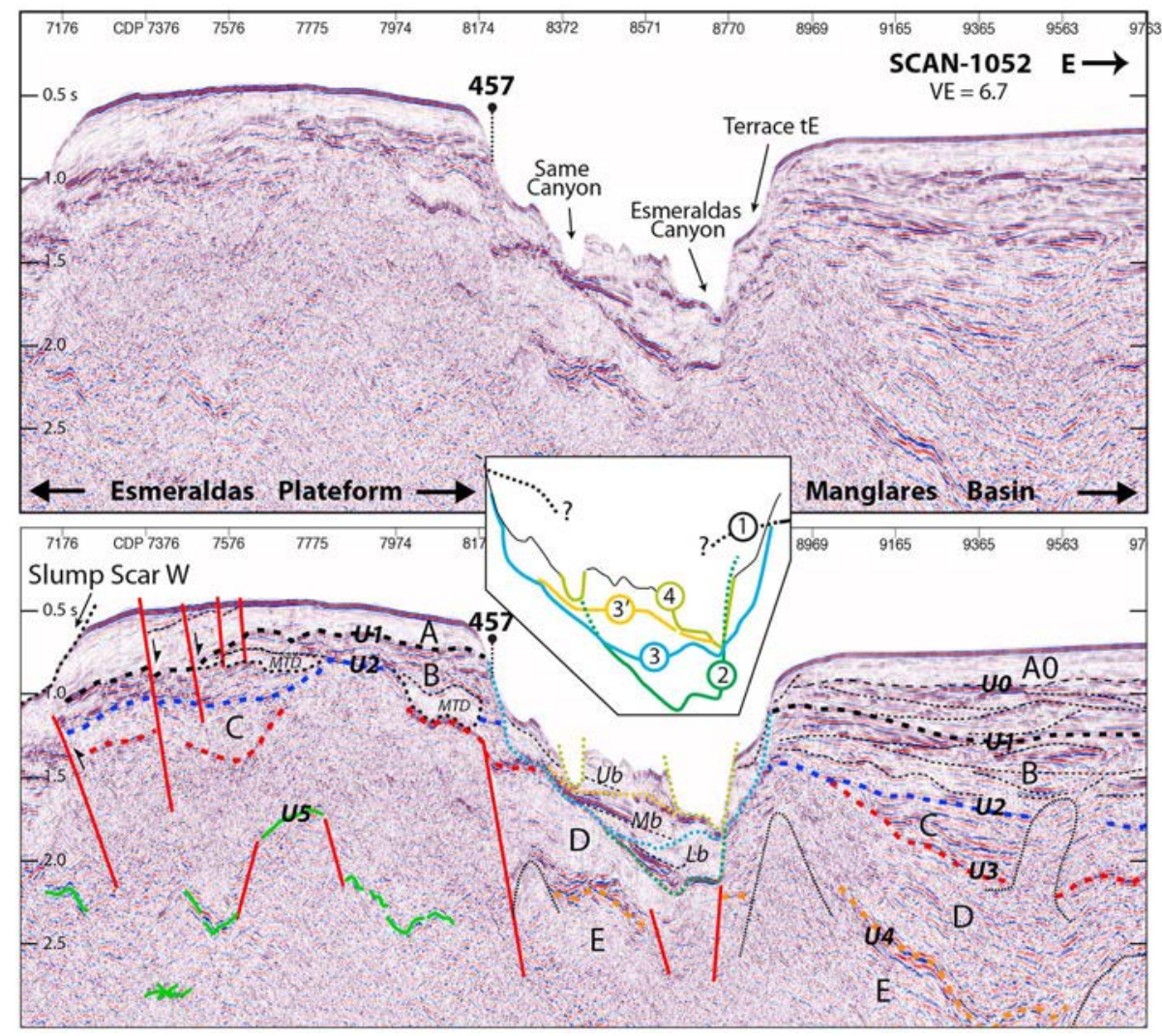

Figure 9. Seismic Reflection Line SCAN-1052 shows evidence for cut-and-fill phases at the junction between the Esmeraldas and Same Canyons; location in Figures 3 and 6b; 457 is Cross Line SCAN-457; seismic units, unconformities, CDP and VE as in Figure 7; thin dotted lines limit fuzzy zones that include a diapiric structure beneath the canyon eastern flank; solid red lines are faults; Note active faults on the western part of the line; Lb, Mb, and Ub are lower, middle, and upper fill series in the canyon; MTD = mass transport deposit, Inset: incision Phases 1, 2, 3, and 4; 3' denotes local unconformity truncating Mb reflectors.

successively NW, north, and NE suggesting a local structural control. Subhorizontal terraces tN and tO (Figure 6c) likely differ in origin as terrace $\mathrm{tN}$ formed in a structurally depressed seafloor area bounded by $\mathrm{NE}$ trending scarps, whereas narrow, N-S elongated terrace tO emplaced within the canyon valley, only $\sim 100 \mathrm{~m}$ above the canyon floor. Further north (Figure 6c), smooth, 10-km-wide, slant amphitheatershaped terrace tP overhangs a morphologically chaotic body (S1) that rims the canyon eastern flank. Ratzov et al. (2007) interpreted these features as the results of a massive gravity-driven event. North of latitude $1^{\circ} 43^{\prime} \mathrm{N}$, the LEC valley widens considerably to $\sim 8 \mathrm{~km}$ before reaching its mouth (Cross Section 16, Figure 4a). At latitude $1^{\circ} 45.5^{\prime} \mathrm{N}$, the LEC thalweg abruptly changes course counterclockwise by $\sim 80^{\circ}$ and drastically reduces its width to $\sim 0.5 \mathrm{~km}$ along the $\sim 5$ - $\mathrm{km}$-long stretch that breaches the subduction front (Figure 6c). Cross Section 16 (Figure 4) and Figure 6c show that this stretch separates flat seafloor Q to the west from the contrasting eastern chaotic morphology of Feature S2. Feature S2 is bounded eastward by a 1,200-m-high scarp (Cross Section 16, Figure 4) that includes a 500-m-high cliff with a $\sim 40^{\circ}$ slope (Figure 5).

\subsubsection{Seismic Structure of the LEC}

The seismic structure of the LEC terraces provides key information about the canyon relative temporal evolution. On Line SCAN-1056 (Figure 11), terrace tG tops a structural block that consists of poorly reflective lower series $c$ that resembles to adjacent Unit $\mathrm{C}$, strongly reflective series $b$ that is similar in dip and facies to the base of Unit B, and series $a$ that returns low-amplitude reflectors similar to those of Unit A. The $\sim 140$-m vertical offset between the block and truncated adjacent Units A, B, and C, as well as the coherency of the block internal architecture suggest that terrace tG tops a slump block. A short subhorizontal reflector underlies by 0.1-s TWTT both the canyon flat-floored thalweg and the toe of terrace tG pointing to a $2.5-\mathrm{km}$ wide, flat-floored paleothalweg (Incision 2 in Figure 11) overlain by deposits left by channelized gravity flow predating the setting up of the slump block (Phase $2^{\prime}$ in inset, Figure 11). 

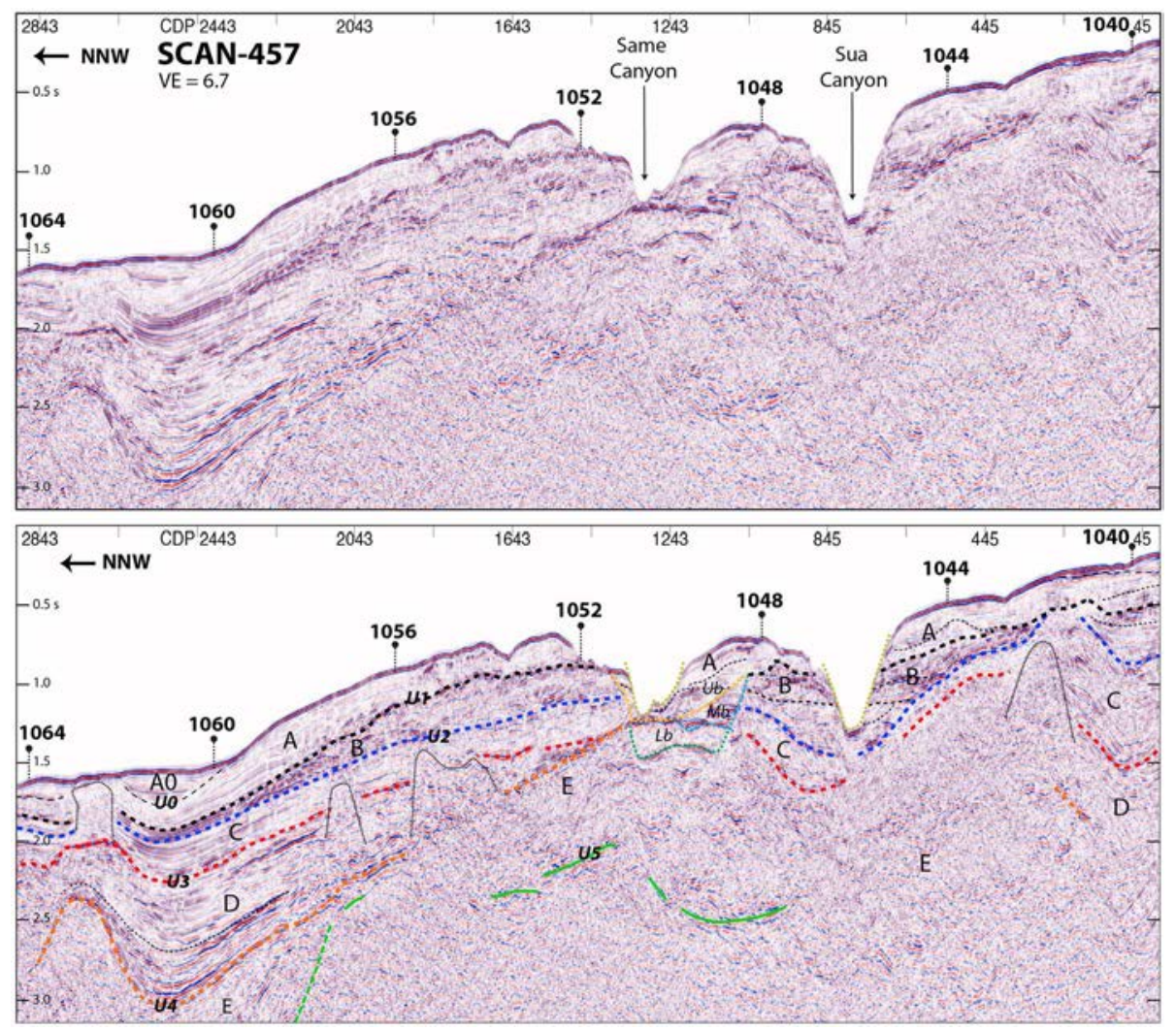

Figure 10. Seismic Reflection Line SCAN-457 shows the stratigraphic context of the Same and Sua Canyons, and the evolution of seismic units northward across the margin upper slope; location in Figure 3; Bold numbers (1060) are Cross Lines SCAN; seismic units, unconformities, CDP and VE as in Figure 7; Lb, Mb, and Ub are lower, middle, and upper fill series in the Same Canyon; incision phases as in Figure 9; thin dotted lines limit diapiric structures (CDP 250 and 2750 ) and uninterpreted fuzzy zones (CDP 1800-2050).

Line SCAN-1060 (Figure 12) images the result of multiple incision and infilling phases of the LEC recorded beneath terraces $\mathrm{tH}$, tI, and tF. On this line, the LEC cuts Units A to D down to Unit E, where the base of the canyon fill is a 5-km-wide, U-shaped, and slightly westward dipping erosion surface. Beneath terraces tH and $\mathrm{tF}$, the canyon fill counts four seismic series: thinly stratified and reflective series $L c$; subtransparent series $M c 1$; chaotic to poorly stratified unit $M c 2$ topped by a high-amplitude, undulating reflector overlain by poorly reflective; and chaotic series $U c$ that is incised by the LEC. Beneath terrace tI, well-stratified subhorizontal series $L s^{*}$ overlain by poorly reflective wedge $U s^{*}$ onlap unconformity $\mathrm{U} 1$ and resembles to adjacent Units A and A0. In contrast, the seismic facies of the series underlying terraces $\mathrm{tH}$ and $\mathrm{tF}$ differ from that of Units $\mathrm{C}$ to $\mathrm{E}$, against which they are in sharp erosive contact. Therefore, the canyon stratigraphic sequence and unconformities suggest that four main phases prevailed in the construction of that part of the LEC. During incision Phase 1 (inset, Figure 12), the canyon carved into Units B and C beneath terrace tI, drawing a meander in map view (Figure 6b), prior to be filled with series $L s^{*}$ and $U s^{*}$, likely during deposition of Units A and A0. During Phase 2, the canyon shifted westward, cut series $L s^{*}$ and Units $\mathrm{C}$ to $\mathrm{E}$, thus deepening and enlarging its valley (Incision 2). Then, series Lc, Mc1, and Mc2 were deposited in the paleocanyon. Series Lc may be composed of turbidites that filled the canyon floor, whereas series $\mathrm{Mcl}$ would reflect more homogeneous muddy sediment, and series Mc2 likely consists of mass flows with an irregular and strongly reflective topography similar to that described by Piper et al. (1999) and Joanne et al. (2013). Subsequently, series Uc that is interpreted as a MTD emplaced across the canyon during Incision Phase 3, likely blocked the passage of gravity flows along the canyon, prior to be incised during Phase 4 (inset in Figure 12). We interpret the steep, semicircular scarp that overhangs terrace tH (Figure 6b) as the source area from which Uc material failed into the canyon.

Line SCAN-1066 (Figure 13) shows unconformity U1 to truncate strata of Units B and C upslope of terrace tK, thus generating a paleovalley that is filled with a well bedded and reflective series similar to $L s^{*}$ on Line SCAN1060. These observations provide an additional evidence for the early Phase 1 of the LEC to be coeval with 


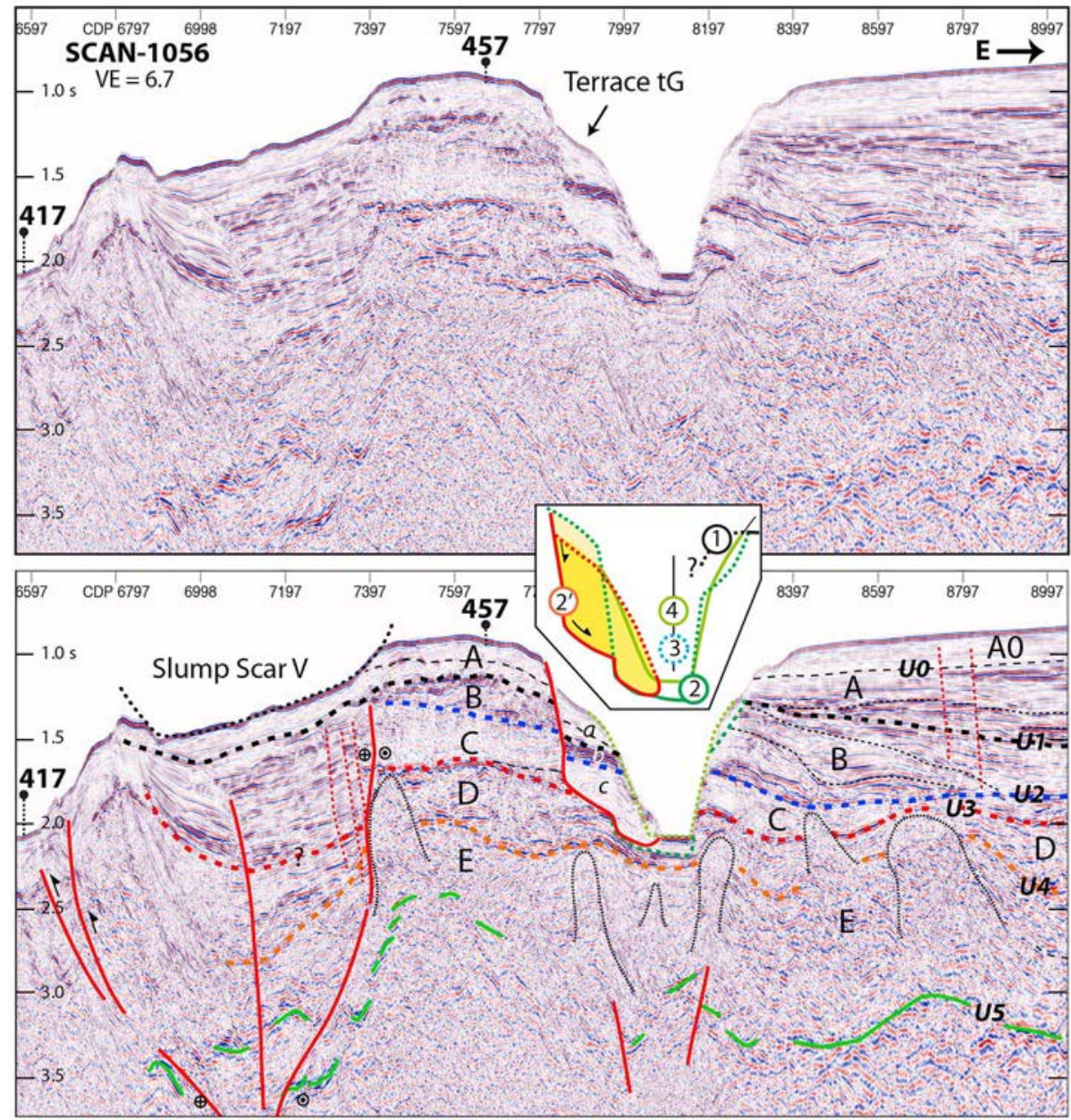

Figure 11. Seismic Reflection Line SCAN-1056 shows evidence for a slump block beneath terrace tG in the Esmeraldas Canyon; location in Figures 3 and $6 \mathrm{~b}$; 417 and 457 are Cross Lines SCAN; seismic units, unconformities, CDP and VE as in Figure 7; solid red lines are faults; note evidence for a flower structure on the western part of the line; Slump scar V is indicated in Figure 3; thin dotted lines as in Figure 9; inset: incision Phases 1, 2, and 4, and local slump Phase 2'.

unconformity U1. A second phase of canyon incision sharply truncated $L s^{*}$ strata and underlying margin units, carving a wide, highly reflective and flat-floored paleocanyon similar to the image of Incision 2 on Line SCAN1060 (Figure 12). The homogeneous weakly reflective infill of Canyon Incision 2 beneath terrace tK denotes, however, a simpler canyon fill history rather than its multistage infill on Line SCAN-1060. The infill of Incision 2 was then sharply truncated, when the canyon shifted westward and deeply incised the margin.

On Line AMA12 (Figure 14a), flat terrace tL emplaced in a paleoincision that cuts unconformity U1. The incision depth and geometry, as well as its infill character mirror those of Incision 2 underlying terrace tK (Figure 13) suggesting that both paleoincisions are coeval, and that terraces tL and tK, which stand astride the LEC thalweg, filled former LEC meanders. Line AMA11 (Figure 14b) across terrace tM reveals an alternation between chaotic and thinly stratified, reflective series $U d$ on lapping strongly reflective series $L d$ thinning away from the LEC and echoing coarse-grained channelized sediments. Dredging at site D12 (Figures $6 \mathrm{c}$ and 14b) recovered compacted mud and siltstone derived from series Ld and possibly Ud. Siltstone samples are dated Pliocene to Middle Pleistocene (Table 1) suggesting that terrace tM recorded the canyon evolution since its initiation (Figure 2), as discussed further below.

\subsection{The AC}

\subsubsection{Morphology of the AC}

The AC strikes NE, parallel to the Ancon fault system (Figure 3). It is $\sim 35-\mathrm{km}$-long from the $875-\mathrm{m}$ water depth of the Manglares Basin, down to its confluence with the EC at a water depth of 2,200 $\mathrm{m}$ (Figure 6d). Along its course, the AC shows a remarkable and unusual 100-m-high saddle (Gastaud, 2010) that 


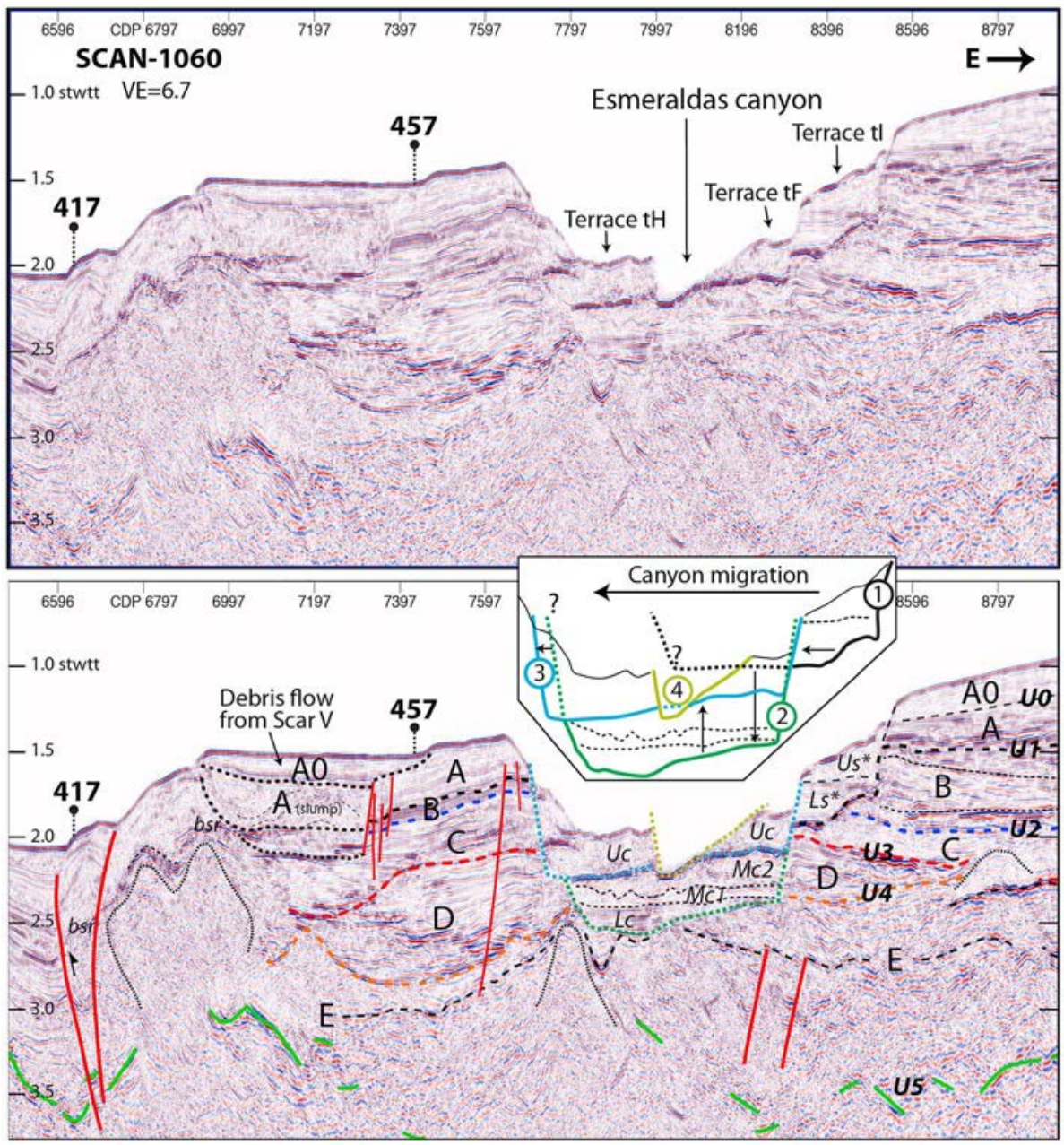

Figure 12. Seismic reflection Line SCAN-1060 shows evidence for cut-and-fill phases and lateral migration of the Esmeraldas Canyon across terraces tH to tI; location in Figures 3 and 6b; seismic units, unconformities, CDP and VE as in Figure 7; Lc, Mc1, Mc2, Uc are lower, middle, and upper fill series beneath terraces tH and tF; Ls* and Us* are lower and upper fill series beneath terrace tI; Solid red lines are faults; note the active fault with a reverse component on the western part of the line; thin dotted lines limit diapiric structures; inset: incisions Phases 1, 2, 3, and 4 and left-lateral migration of the canyon; Uc denotes mass transport deposits on top of series Mc2.

divides the canyon in two segments with opposite flow directions. (1) The short eastward dipping stretch incises loosely the basin slope, thus heading toward the Manglares Basin (Figures $4 \mathrm{c}$ and $6 \mathrm{~d}$ ), where the canyon has no seafloor expression, although its buried incision is imaged on seismic sections up to a triple collector east of the Ostiones Swell (Figure 3). (2) The prominent westward dipping segment consists of short 2to 4-km-long, linear stretches with V-shaped cross sections and flanked by small terraces (Figure 4b). Where joining the EC, the AC divides in two short reaches that incise the margin topography by up to $700 \mathrm{~m}$. While the $\mathrm{AC}$ southern reach is shallower than the northern one and seems abandoned, the northern reach bends westward and connects smoothly with the EC. These observations indicate that the east and west dipping AC stretches were once part of a single west dipping canyon carrying spillover particles coming from the Manglares Basin.

\subsubsection{Seismic Structure of the AC}

Line AMA66 (Figure 14d) cuts across the AC and shows that margin layers are deformed into a large anticline, the apex of which is incised by the AC. In map view, the AC cuts sharply the anticline axis indicating that the canyon did establish prior to the anticline growth. The lack of evidence of lateral migration of the AC valley supports a rapid topographic inversion. Presumably, strong canyon erosion overcame the anticline growth, thus keeping pace with uplift. Further upslope in the Manglares Basin, Line AMA 16 (Figures 3 and 15) shows evidence for the upper valley of the AC to be buried beneath 0.17-s TWTT of sediment, providing indication for the canyon to be cut from its main source of sediment supply. 


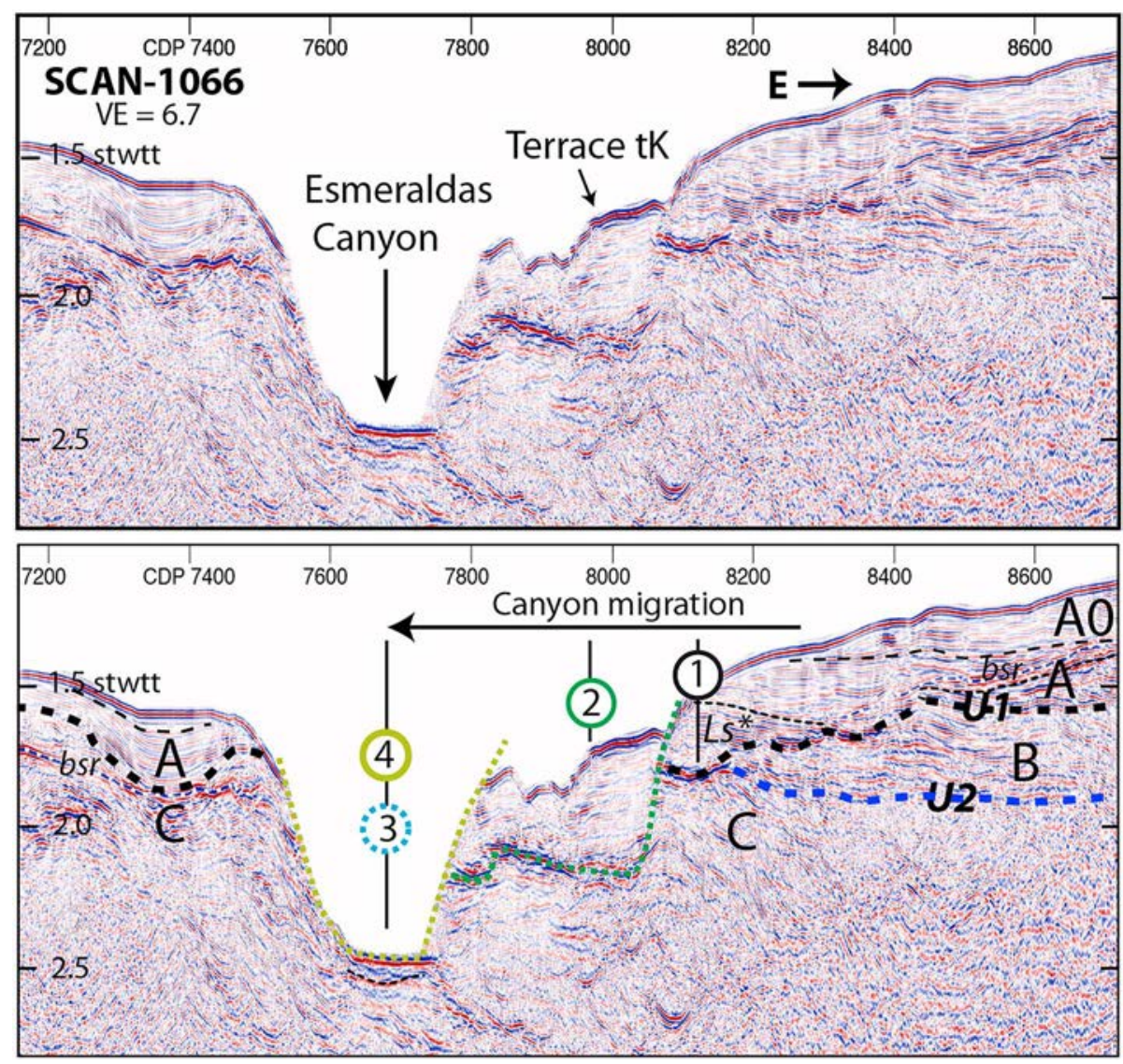

Figure 13. Seismic reflection Line SCAN-1066 shows evidence for cut-and-fill phases and left lateral migration of the Esmeraldas Canyon across terraces tK; location in Figures 3 and 6b; seismic units, unconformities, CDP and VE as in Figure 7; Ls* is lower fill series equivalent to Ls* in Figure 12; Incision 1 is continuous with unconformity U1 suggesting synchronicity. Sediment fill of Incision 2 is equivalent to series Lc, Mc1, and Mc2 in Figure 12; axial Incision 4; Incision 3 has not been observed here; bsr is bottom-simulating reflector.

\section{Discussion}

\subsection{From Basin Subsidence to the EC Onset}

Although the geological history of the North Ecuador margin is long and complex, we will consider its evolution only from Unit $\mathrm{C}$ to put the formation of the $\mathrm{EC}$ in its paleoenvironment and tectonic context. From its low-amplitude layered seismic facies and large-scale basin shape (Figure 7), Unit $\mathrm{C}$ is interpreted as a basin floor structure filled with fine-grained sediment. The overlying Unit B consists of superimposed lens-shaped bodies showing lateral changes of seismic facies from narrow, highamplitude packages to low-amplitude reflections that suggest occurrences of migrating nested channel fills and lobe deposits (Figures 7-9 and 11). This organization provides evidence for either a slope fan possibly fed by a canyon (e.g., Covault et al., 2007), or a network of deltaic channels, (Heller \& Dickinson, 1985; Shanmugam, 2016). The coalescent lobes and scarce distributary channels imaged in Unit B, together with the lack of evidence of a fossil feeder canyon onshore support a multiple source ramps or better, a slope apron origin (Stow \& Mayall, 2000).

The sharp contrast between the slope apron paleoenvironment of Unit B and that of underlying Unit $\mathrm{C}$ basin floor sediment (Figure 7) implies a significant change in regional paleotopography and paleodepth that is coeval with unconformity U2. Unit $\mathrm{C}$, which is inferred to be a time equivalent of the Viche Formation (Figure 2; (Marcaillou \& Collot, 2008), deposited at bathyal depths (Cantalamessa et al., 2007; Evans \& Wittaker, 1982) during the Lower to Middle Miocene subsidence of the Manglares Basin (Lopez Ramos, 2009). Unit B is considered a time equivalent of the Lower Onzole and Angostura Formations based on regional correlations (Marcaillou \& Collot, 2008; Figure 2) and Late Miocene to late Early Pliocene sediment 


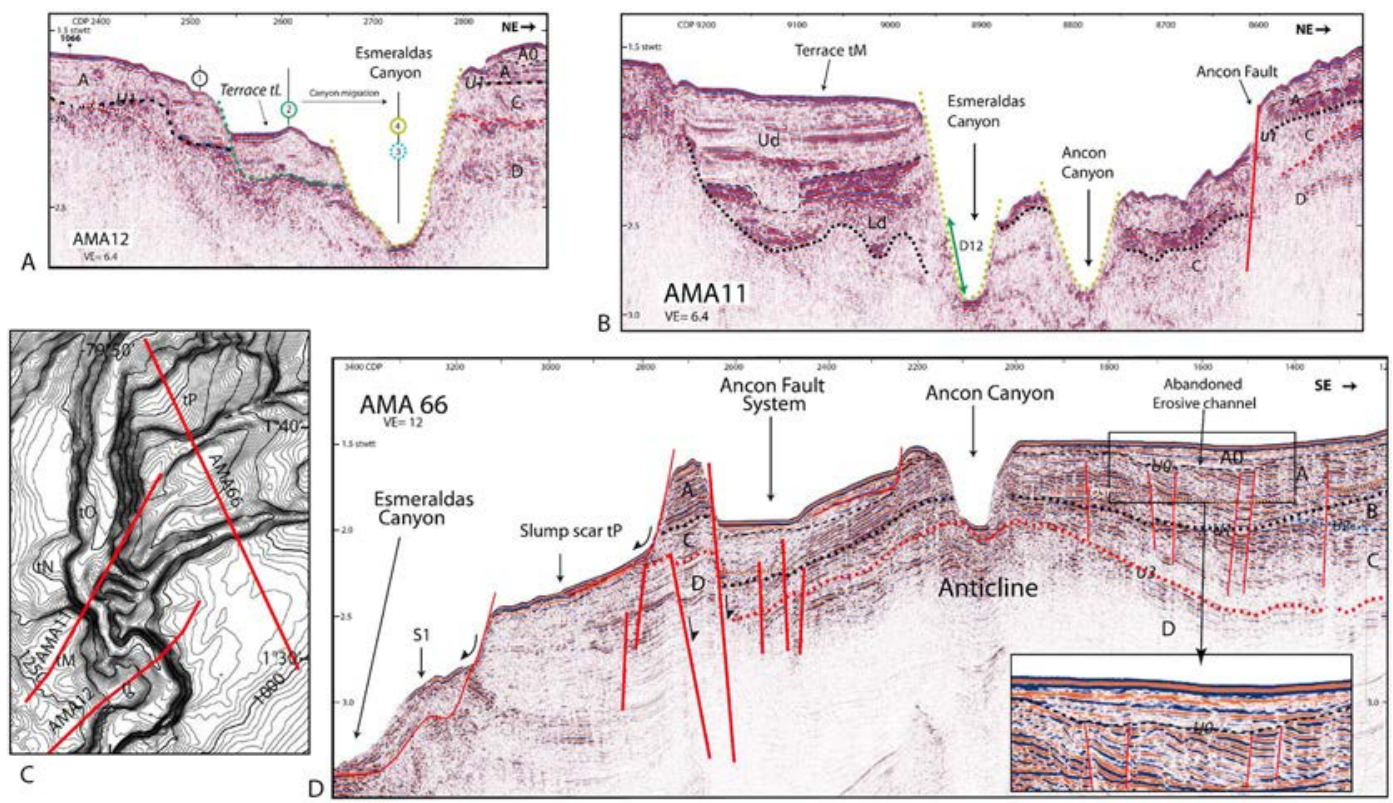

Figure 14. Seismic reflection lines AMA across the Lower Esmeraldas Canyon and Ancon Canyon; seismic units, unconformities, CDP and VE as in Figure 7; (a) Line AMA12 across terrace tL showing a mirror image of Line SCAN-1066 structures in Figure 13, where Incision 2 cuts U1; present-day Incision 4 is shown; (b) Line AMA11 cuts across terrace tM and the Ancon fault system; D12 is rock dredging (Table 1); Ld, and Ud are lower and upper series; (c) location map; (d) Line AMA66 showing the apex of an anticline incised by the Ancon Canyon; solid red lines are fault branches of the Ancon fault system; terrace tP features the scar of a slump mass failed in the Esmeraldas Canyon; Inset is a zoom on an abandoned spillway channel from the Manglares Basin.

recovered in dredge D13. Both the Lower Onzole and Angostura Formations were deposited in variable water depths including very shallow waters (Cantalamessa et al., 2007; Deniaud, 2000; Evans \& Wittaker, 1982; Ordonez et al., 2006; Reyes, 2013). Accordingly, the middle to upper Miocene shelf detrital sediments of these formations are interpreted to change laterally to slope apron deposits on the Manglares Basin southern flank. Hence, unconformity U2 marks a major 12- to 13-Ma-old tectonic episode (Figure 2) that deformed and uplifted the margin prior to Unit B deposition. Uplift of the Esmeraldas Platform went on during and after deposition of Unit B as shown by Unit B internal MTDs (Figure 9) and the warping up of Unit B across the EC and platform (Figures 8 and 9). These views imply that the EC, which bypasses the Esmeraldas Platform, postdates unconformity U2. Indeed, Incision 1, which is the EC oldest incision interpreted on seismic sections, truncates Units B and C and correlates spatially with unconformity U1 (Figures 8,12 and 13) dated from the Miocene-Pliocene boundary (Figure 2), suggesting that the EC inception occurred $~ 5.3 \mathrm{Ma}$ ago.

\subsection{Lateral Migration and Deepening of the EC: A Response to Uplift Events and Glacioeustatic Variations}

Seafloor deformation commonly affects submarine canyon systems (Greene et al., 1991; Huyghe et al., 2004; Laursen \& Normark, 2002; Mountjoy et al., 2009). In Ecuador, in the region of terraces tL and tM, the EC migrated eastward (Figure 16) possibly driven by local uplift in response to seaward verging, reverse faulting along the lower margin slope (Figures 1 and 12). In contrast, south of latitude $1^{\circ} 28^{\prime} \mathrm{N}$, the canyon valley has steadily migrated toward the left bank of the canyon as revealed by geomorphological evidences (Figures 6a and $6 \mathrm{~b}$ ) and the systematic left-hand shift of nested incisions beneath terraces tB, tC, tD, tI-tF, and tK (Figures 12 and 13). The canyon migration differs from meander avulsions and cutoff loops that could occur on both sides of a channel on a stable passive margin in relation to sea level variations (Babonneau et al., 2004; Sylvester et al., 2011). Here, because EC Incision 1 is spatially associated with the Ostiones Swell and because the canyon migrated left-laterally by steps between Incisions 1, 2, and 3 (Figures 8, 12 and 13), we suggest that the canyon migration responded to the tectonic growth of the NE trending Ostiones Swell (Figure 16). Additionally, each step of the canyon migration was accompanied by a deep incision in the margin, reaching 400-600 $\mathrm{m}$ in depth. Such remarkable deepening of the canyon requires strong erosion driven by an increased flux of particles funneled in the canyon likely in response to glacioeustatic variations 


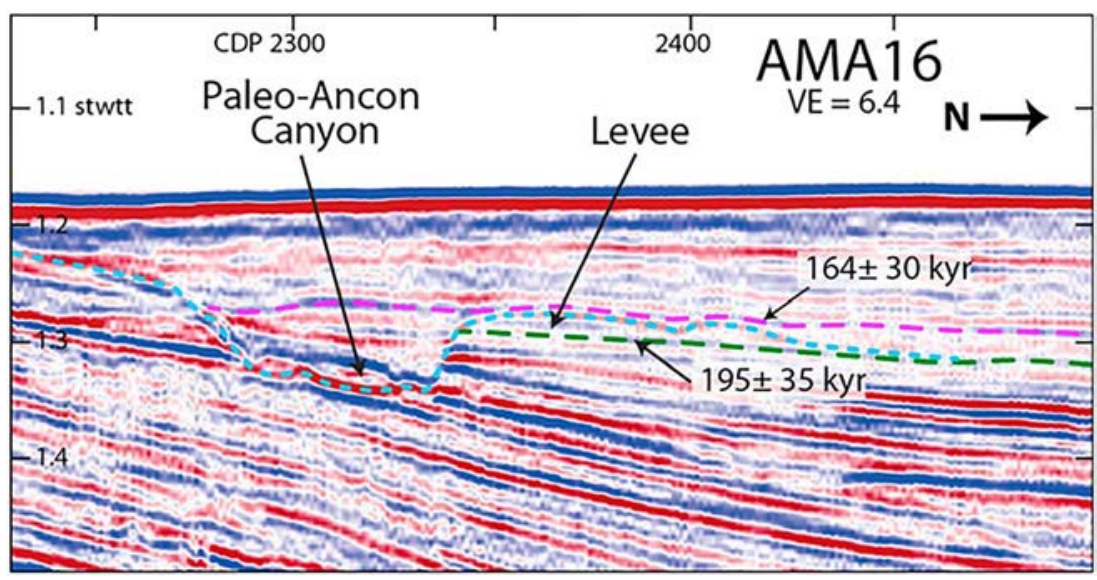

Figure 15. 3Seismic reflection line AMA16 showing the buried section of the Ancon canyon; ages of black and pink dashed horizons are derived from ${ }^{14} \mathrm{C}$ dating on sediment from KAMA 17 and 18 cores; location in Figure 3.

and uplift events. On the one hand, local uplift events related to the tectonic activity of the Ancon fault system and subduction front contributed to the deep erosion of the LEC north of latitude $1^{\circ} 28^{\prime} \mathrm{N}$. On the other hand, the growth of the Ostiones Swell, which controlled the evolution of the EC south of this latitude, occurred during the Late Miocene to Pleistocene regional tectonic events that uplifted the coastal range such as the Businga anticline structure (Evans \& Wittaker, 1982; Reyes, 2013), which shows a common NE structural direction with the Ostiones Swell (Figure 1).

The depth distribution of Incision 2 along the EC (Figure 4c) supports the occurrence of an uplift of variable amplitude that postdates at least Incision 2. The EC stretch imaged on Lines SCAN 1052 and 1060 shows Incision 2 to be deeper than the EC thalweg and to have preserved part of its infilling (Figure 12), although Incision 3 deeply cut the margin during the subsequent uplift phase (Figure 9). In contrast, upstream and downstream of the canyon stretch crossed by SCAN Lines 1052 and 1060, the preserved traces of Incision 2 reveal shallower than the canyon thalweg (Figure 4c). Considering the longitudinal depth profile of Incision 2 to have been roughly linear, this observation means that the canyon stretches located upstream and downstream of the one crossed by SCAN lines 1052 and 1060 were uplifted by $\sim 300-450 \mathrm{~m}$ since the infill of Incision 2.

Precise ages of the regional uplift events associated with the EC incisions are difficult to estimate but can be bracketed. According to Reyes and Michaud (2012), the lower part of the Upper Onzole Formation, named Lower Borbon and Sua members (Figure 2), extends along most of the Ecuador coastal range. Reyes (2013) reported a regional Middle Pliocene uplift episode marked by an angular unconformity that truncates the Lower Borbon member deposits (Figure 2). According to this author, the Canande Fault, interpreted as a north dipping, reverse fault, may have been reactivated at that time, thus uplifting the crustal block north of the fault (Figure 1). The Middle Pliocene uplift episode, which succeeded the EC inception, could be associated with Incision 2 of the EC (Figure 2). In this hypothesis, the sediment fill of Incision 2 would be coeval with the Middle Borbon member. The Pliocene to Early Pleistocene age of sediment dredged at Sites D14 and D12 (Table 1) is consistent with this suggestion. Incision Phase 3 may result from one of the latest coastal uplift events identified by Evans and Wittaker (1982) as post-late Pliocene. Indeed, south of the Canande Fault (Figure 1) in the region of Jama, the Upper Borbon member consists of shallow marine deposits dated $1.6 \pm 0.06 \mathrm{Ma}$ (Cantalamessa et al., 2005) to $0.8 \pm 0.1 \mathrm{Ma}$ (Reyes, 2013) from ${ }^{40} \mathrm{Ar} /{ }^{39} \mathrm{Ar}$ dating on ash products. The member overlies unconformably the Middle Borbon member, pointing to a prominent early Pleistocene uplift event (Reyes, 2013). The subsequent uplift of the Upper Borbon member to an altitude of $\sim 400 \mathrm{~m}$ southeast of Jama (Reyes, 2013) together with uplifted marine terraces dated 98 and $220 \mathrm{ka}$ in the Punta Galera region (Pedoja et al., 2006) support a middle to late Pleistocene phase of uplift (Figure 2). Therefore, in addition to Incision 2 of the EC that reflects a mid-Pliocene uplift event, Incisions 3 and 4 are tentatively associated with early Pleistocene, and middle to late Pleistocene uplift events that affected both the coastal and offshore regions of Ecuador. Considering the variable depth of Incision 2 along the EC (Figure 4c), and a 1.8- to 2-Ma age for Incision 3, a 0.15-0.25 mm/year 


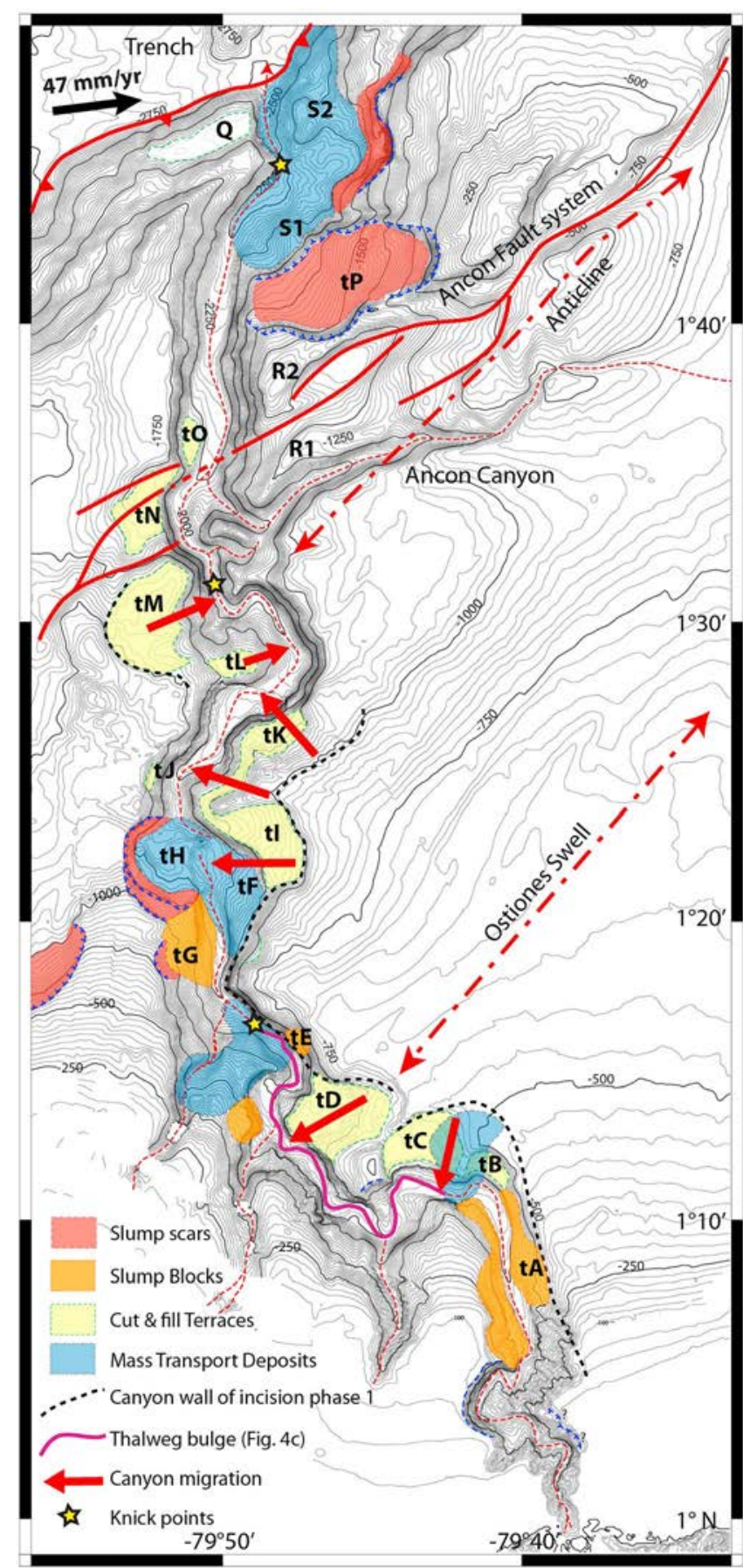

Figure 16. Geological interpretation of the study area showing simplified bathymetry, cut and fill canyon terraces, slump scars, slump blocks and mass transport deposits; note that left-lateral migration of the southern half of the Esmeraldas Canyon is associated with the tectonic growth of the Ostiones Swell.
Pleistocene uplift rate is inferred to have affected dominantly the regions of the Ostiones Swell axis, the Ancon fault system and the subduction front.

Pliocene-Pleistocene sea level oscillations likely played a fundamental role in the development of the EC as suggested in other areas (Baztan et al., 2005; Bertoni \& Cartwright, 2005). Although, recurring periods of rapid sea level fall would have contributed to the EC erosion (Bertoni \& Cartwright, 2005; Rasmussen, 1994), the very short, distance $(<1 \mathrm{~km})$ between the present-day EC head at the mouth of the Esmeraldas River and the $-120-\mathrm{m}$ bathymetric contour (Figure 6a), a marker of the youngest low sea level stand, points to a long-term canyon-river connection that discards any major control of sea level changes on sediment fluxes entering the UEC. On the contrary, the 10- to 40-km across-shelf distance between the small rivers mouth (Figure 1) and the heads of the Atacames, Sua, and Same Canyons, which coincide with the 120-m depth curve (Figure 6a), indicate that, during the Pliocene to Quaternary net sea level falls, especially over the last $\sim 600 \mathrm{kyr}$ when the sea level low stands dropped from -80 to $-120 \mathrm{~m}$ (Hansen et al., 2013; Miller et al., 2005), an additional flux of particles was funneled to the EC via the tributary canyons, thus increasing the EC overall erosive power. In addition, the high flux of water produced during the Pleistocene melting periods of the Andean glaciers, combined with lahars related to the volcanic activity that intensified during the early Pleistocene (Barberi et al., 1988) likely augmented offshore sediment delivery, and hence assisted the youngest canyon incision phases.

Middle Pliocene Incision 2 occurred when the average, long-term sea level started lowering below the modern sea level, that is, 3.5-3.0 Ma ago (Hansen et al., 2013), and the incision depth was possibly increased during the prominent sea level fall at 3.3 Ma (Miller et al., 2005). Considering that ensuing Incision 3 occurred during an early Pleistocene uplift event, the incision was definitely affected by the middle to late Pleistocene 100 -kyr glacioeustatic cycles. In this hypothesis, whatever the origin of series $\mathrm{Mb}$ and $\mathrm{Ub}$ infilling the Same Canyon and the EC near at their junction, the change of the reflectivity within the series and the occurrence of their bounding unconformities (Figures 9 and 10) suggests a variation of the sediment supply controlled by sea level variations. Accordingly, series $\mathrm{Mb}$ and $\mathrm{Ub}$ could have been emplaced during middle to late Pleistocene periods of low sea level stands and continuous sea level rises (Rasmussen, 1994). The MTD of series Uc in Line SCAN 1060 (Figure 12) may be coeval with series $\mathrm{Mb}$ and $\mathrm{Ub}$ (Figure 9). Elsewhere along the EC (Figures 8, 11 and 13), the post Incision 3, canyon infill series were either nondeposited or fully eroded together with the trace of Incision 3 and locally older incisions, as a result of the combined effects of both the most recent uplift events and high-amplitude sea level fluctuations, giving way to deep axial Incision 4.

\subsection{Longitudinal Canyon Depth Profile Anomalies as Evidences for Recent Margin Vertical Deformation}

According to Covault et al. (2011), recent canyons and channel systems across convergent margins show convex-up longitudinal depth profiles, such as in the San Antonio Canyon in Chile (Hagen et al., 1996), the Kushiro Canyon in Japan, (Noda et al., 2008), and La Aguja and Patia Canyons in Colombia (Ratzov et al., 2012; Restrepo-Correa \& Ojeda, 2010). Although running across a convergent margin, the EC shows an overall linear, $1^{\circ}$ dipping longitudinal depth profile indicating that the canyon is close to equilibrium, 
that is, that the erosion roughly balances tectonic growth (Figure 4c). This linear profile contrasts with the convex-up profile of the nearby Patia Canyon where tectonic uplift overcomes canyon erosion (Figure $7 \mathrm{~b}$ in Ratzov et al., 2012). Two major differences between the geological settings of these canyons may account for this distinction. (1) Margin contraction faulting and folding is more active northwest of Tumaco than in the deep-water Manglares Basin (Collot et al., 2004; Figure 1); (2) gravity flows along the EC are frequent as indicated by the canyon permanent connection with its feeder-river and the growing trench turbidite system (Migeon et al., 2017), whereas they have largely decreased along the Patia Canyon as substantiated by its disconnection from its river, its damming by a landslide, and the quasi inactivity of the channel-levee system in the Colombia trench (Ratzov et al., 2012).

The EC longitudinal depth profile shows, however, a 50-m-high bulge and knick points reflecting potential tectonic causes (Figure 4c). The bulge visible along the MEC thalweg between 900 and 1,400 m of water depths is not related to sedimentary causes such as a MTD, which would have dammed the canyon, but suggests that active seafloor bulging locally overcomes the canyon erosion. Knick Point 1 located immediately downstream of the bulge suggests active downcutting by the canyon as gravity flow strives to reestablish a smoothed out profile (e.g., Huyghe et al., 2004). Cross Section 7 in Figure 4a, which cuts the canyon upstream of Knick Point 1, is V-shaped and contrasts with the U-shaped sections directly upstream and downstream (Cross Sections 6 and 8 in Figure 4a), thus supporting active local incision in response to the bulging of the MEC thalweg. The area of active bulging along the MEC depth profile extends perpendicularly to the NE trending axis of the Ostiones Swell (Figure 16), thus supporting the active growth of the swell and uplift of the Esmeraldas Platform.

Knick Point 2 at 2,100 m of water depth features a 50-m-high jump of the thalweg. It roughly coincides spatially with the crossing of the LEC by the NE trending Ancon fault system suggesting a causal link. Near the mouth of the EC, Knick Point 3 coincides with the sharp bend and the narrowing of the LEC thalweg, a saddle and a $3.5^{\circ}$ slope toward the trench, pointing to the canyon forcing its way through an obstacle, here a massive avalanche deposit as discussed further below.

\subsection{Role of Structural Features in the Localization of the EC and Its Upper Margin Tributary Canyons}

Diapiric structures are ubiquitous beneath the upper margin slope where they are dominantly hosted in Unit E. They deform seismic units below the EC valley and its tributary canyons (Figures 7 and 9), suggesting that diapiric structures have had a key influence on their location. In the region of the Atacames and Sua Canyons, diapiric intrusions have folded both Unit C and unconformity U2 (Figures 7 and 10), thus creating syncline paleovalleys between diapiric highs prior to the first incision stages of the canyons. The tributary canyons may have been initially chartered by the small intervening synclines, which likely guided the early gravity flows, prior to incise more deeply Unit B (Figures 7 and 10). The tributary canyons were possibly alimented by slope sediment remobilization, although particles delivered by small rivers (Figure 1) that breached the shelf during sea level low stands likely contributed to the tributary canyons development. In contrast with the Atacames and Sua Canyons, the Same Canyon likely originated from a gravity-driven paleoscar (Figure 10, CDP 1050-1350), as the scar propagated headward (e.g., in Farre et al., 1983; Pratson \& Coakley, 1996) and filled up with MTD and overlying thinly stratified sediment. The MTD experienced differential compaction (Joanne et al., 2010), which would have contributed to destabilize overlying sediment, thus easing the development of the Same Canyon.

Although crustal faults are difficult to identify below the EC, seismic diffractions as well as vertical offsets of basin and oceanic basement reflectors advocate crustal faults. Because the canyon consists of a succession of linear stretches with preferential north, NW, and NE directions, such faults are suspected to tectonically control directly or indirectly the canyon path. For example, faults and folds associated with the EC flanks (Figures 8, 9, 11 and 12) may have controlled the canyon setting and evolution, as well as the fault-related, gentle folds of Units C and D that underlay the UEC (Figure 7) possibly facilitated the canyon localization. On a larger scale, the N-S trend of the LEC, which is oblique to the NW facing margin slope gradient, may be controlled by deeper crustal structures.

The interaction between the EC and the NE trending Ancon fault system may have disturbed the course of the canyon in the form of an apparent left-lateral offset of the short canyon segment facing terrace tN (Figure 
6c). Conversely, a right-lateral offset of the canyon could be suggested on the basis of the abrupt widening of the canyon thalweg from $<1 \mathrm{~km}$ south of the canyon-fault intersection to $\sim 2 \mathrm{~km}$ north of it, according to the canyon erosion model across a strike-slip fault proposed by Appelgate et al. (1992). However, enhanced erosion of the EC western wall flanking terrace $\mathrm{tN}$, in response to focused additional gravity flows carried along the $\mathrm{AC}$, likely contributed to the apparent left-lateral offset.

\subsection{Slope Instability and Role of MTD in Damming the EC}

Gravity flows along the EC were likely blocked by MTDs identified along the canyon valley (Figures 8, 9 and 6a). The recent MTD underlying terrace tH (Uc in Figure 12) dammed the EC prior to be partly eroded. Core Kama 24 collected on terrace $\mathrm{tH}$ (Figure $6 \mathrm{~b}$ ) recovered $3.73 \mathrm{~m}$ of sandy turbidites blanketing the slump mass (Leclerc, 2016). ${ }^{14} \mathrm{C}$ dating of wood fragments sampled at 224 and $308 \mathrm{~cm}$ along the core provided, respectively, 145 years $\mathrm{BP} \pm 15$ and 10,725 years $\mathrm{BP} \pm 30$ ages, indicating that the MTD emplaced prior to 10,725 years. The steep arcuate scarp from which this MTD originated (Figure 6b) together with two other relatively fresh morphologic scars ( $\mathrm{V}$ and $\mathrm{W}$ in Figure 3 ) supports a highly unstable upper margin slope associated with the Esmeraldas Platform uplift and active faulting (Figure 1 and CDP 6600 in Figures 11 and 12; CDP 7200-7600 in Figure 9). This instability is critically augmented in the EC as basal erosion over steepens its flanks. Interestingly, the slump block that underlies terrace tG (Figure 11) did not crumbled down so far but remained suspended and partially obstructed the canyon valley.

At the canyon mouth, a massive landslide may have blocked the LEC (Figure 16). At this location, the drastic width reduction of the LEC valley from $\sim 8$ to $2 \mathrm{~km}$ suggests that the wide canyon valley that once reached the trench, has been plugged before the canyon changes its course by $80^{\circ}$ to breach the deformation front (Figure 6c). The contrasting morphologies between the left (Q) and right banks (S2) of the narrow canyon stretch support this interpretation, which is reinforced by the large slump scars overhanging both Features S1 (tP in Figure 14d) and S2. Accordingly, if this assumption were true, the delivery of particles to the trench would have been mostly interrupted when the canyon mouth was dammed. Seismic Line 10032 (Figure 17) shot across the trench turbidite system reveals two remarkable unconformities separating sedimentary series with contrasting reflectivity. The highly reflective and thinly stratified series $U e$ features levee deposits that laid over the poorly reflective and well-stratified strata of series $\mathrm{Me}$. Series Me laps onto an erosive unconformity that tops underlying highly reflective and tectonically deformed series $L e$. The relative weak reflectivity of series Me may indicate a more homogeneous unit enriched in pelagic sediment and containing comparatively less turbidite deposits than series Ue and Le. The change from Le to Me thus suggests a sharp decrease of turbidite supply in the trench over a long time laps that we interpret as the damming of the canyon valley by the landslide. During this period, probably only the finest-grained fraction of turbidites was able to overspill the dam and deposit in the trench.

A return to a turbidite-enriched sedimentation such as interpreted in series Ue and retrieved in core KAMA 21 in the trench channel-levee system (Figure 3; Migeon et al., 2017), occurred when the landslide was cleared enough by gravity flows and the canyon broke the plug. This scenario suggests that when the canyon was plugged, turbidite dominant sedimentation accumulated in the canyon valley upstream of the plug. Breaking the plug favored terraces formation possibly as terrace tO by resumption of the canyon incision. The unconformities separating series $\mathrm{Ue}, \mathrm{Me}$, and Le are tentatively dated $27 \mathrm{kyr} \pm 6.7 \mathrm{kyr}$ for the shallowest and $65 \mathrm{kyr} \pm 6.7 \mathrm{kyr}$ for the deepest on the basis of a mean sedimentation rate of $0.67 \mathrm{~cm} /$ year obtained from core KAMA21 (Migeon et al., 2017). The 65-kyr age is, however, underestimated since the sedimentation rate of turbidite-depleted series Me is likely lower than that of series Ue. These ages imply (1) that prior to $\sim 65 \mathrm{kyr}$ an event caused a slope collapse sufficiently large to clog the canyon and (2) over $\sim 38 \mathrm{kyr}$ were necessary for the canyon activity to breach the dam. Because the EC is considered the main source for sediment to be remobilized during regional large earthquakes (Migeon et al., 2017), landslide events blocking the EC have significant implications as they may introduce time gaps in the trench paleoseismology records.

\subsection{Timing of the Deformation and Abandonment of the AC}

As illustrated along the Chilean margin, tectonic deformation can block the development of a canyon (Bernhardt et al., 2015). In the Manglares Basin, the AC, which acted as the main spillway of the basin, was deformed recently by a growing anticline associated to a crustal splay fault (Collot et al., 2008). The youngest basin horizon to be truncated by the AC along Line AMA16 (Figure 15) is dated $195 \mathrm{kyr} \pm 35$ 


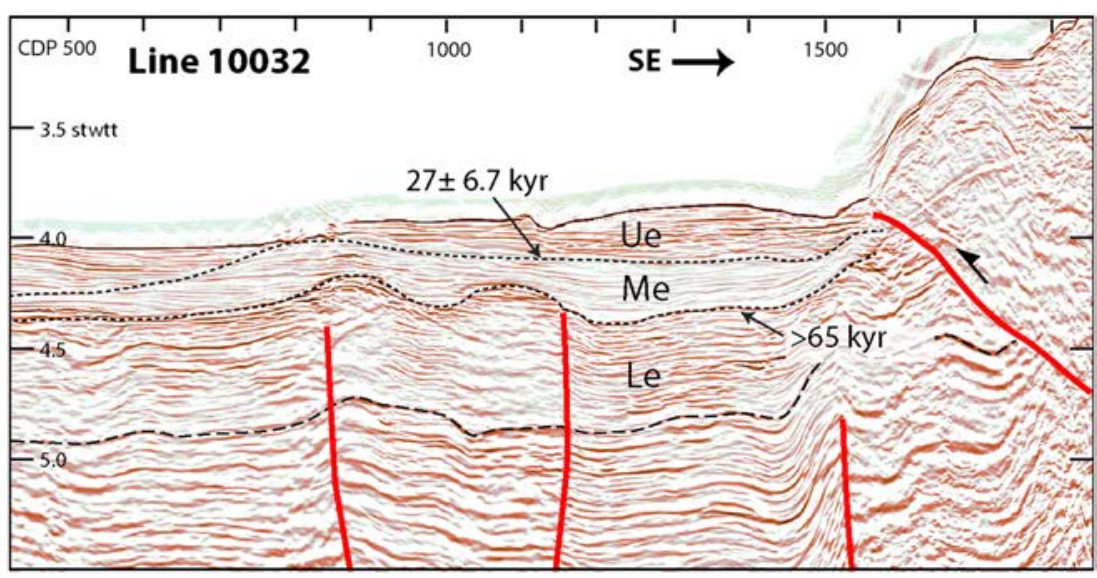

Figure 17. Seismic reflection Line 10032 across the Colombia trench fill, near the mouth of the Esmeraldas Canyon; faults in red; Le, Me, and Ue are lower, middle, and upper trench fill series; dotted lines are unconformities between series; note Me low reflectivity contrasting with Ue and Le higher reflectivity; ages of unconformities are derived from ${ }^{14} \mathrm{C}$ dating on sediment from KAMA 21 core (Migeon et al., 2017); see Figure 3 for location.

kyr. This age is obtained from an average sedimentation rate of $0.62 \mathrm{~mm} /$ year calculated on the basis of ${ }^{14} \mathrm{C}$ dates obtained from foraminifers sampled in cores Kama17 and 18 located along Line AMA16 (Figure 3; Gastaud, 2010). A small levee complex built on the buried canyon northern rim (Figure 15) above the dated truncated horizon, implies that the canyon was active $195 \mathrm{kyr}$ ago. The top horizon of the canyon fill, which is dated $164 \mathrm{kyr} \pm 30 \mathrm{kyr}$ along Line AMA16, benchmarks the canyon abandonment. A conservative $\sim 1,050$-m initial water depth of the canyon thalweg beneath the saddle, based on the $\sim 1,000$ $m$ depth of the buried canyon bottom on AMA16, implies that the anticline responsible for the saddle had to grow up by $\sim 50 \mathrm{~m}$ (Figure 4c) between 195 and $165 \mathrm{kyr}$ at an $\sim 1.6-\mathrm{mm} /$ year rate to reach a $0^{\circ}$ downstream slope, so that the canyon ceased being a spillway channel of the Manglares Basin. Since the canyon abandonment, the anticline kept growing at $\sim 1.6 \mathrm{~mm} /$ year to reach the present-day $750-\mathrm{m}$ water depth in the saddle. After the closure of the AC, the sediment pathway from the Manglares Basin to the EC migrated southward and remained active for a short time period as indicated by an abandoned erosive channel (Figures 3 and 14d). This tectonic process illustrates a mechanism by which a fore-arc basin fills up.

\subsection{Potential Role of Carnegie Ridge Subduction on the EC Formation}

The uplift of the Ecuador forearc that accompanied the construction of the submarine slope apron and the development of the EC over the last 12-13 Ma occurred during a global convergence rate decrease between Nazca and South American Plates (Pardo-Casas \& Molnar, 1987; Somoza \& Ghidella, 2012). However, the South American Plate has been advancing over the Nazca Plate at least since $~ 5.8$ Myr so that the trench migrates westward at 17-28 mm/year (Gripp \& Gordon, 2002; Heuret \& Lallemand, 2005). According to Lallemand et al. (2005), continental advancing upper plates correlate with low slab dips $\left(<30^{\circ}\right)$ and upper plate back-arc compression. Such a geodynamic framework encountered in Ecuador (Lonsdale, 1978; Manchuel et al., 2011; Nocquet et al., 2014; Trenkamp et al., 2002) favored uplift and contraction across the subduction zone, though the subduction of the Carnegie Ridge (CR) likely influenced the PliocenePleistocene deformation pattern (Aalto \& Miller, 1999; Gutscher et al., 1999; Lonsdale, 1978; Pedoja et al., 2006). Indeed, the inception of the EC $~ 5.3 \mathrm{Ma}$ ago coincides with (1) an uplift of the northern Ecuador coastal area (Di Celma et al., 2010) (Reyes, 2013), (2) an 1-km uplift of most the coastal range since the early Pliocene as deduced from detrital apatite and zircon ages (Vacherat et al., 2017), and (3) a rise of elevated exhumation rates that initiated between 5.5 and 3.5 Ma within the Western and Northeastern Cordilleras, which Spikings et al. (2010) tentatively associated with the subduction of the Carnegie Ridge. A reappraisal of the Carnegie Ridge subduction model proposed by Collot et al. (2009), using the plate convergence kinematic result of Nocquet et al. (2014), suggests that the Carnegie Ridge entered subduction 5-6 Ma ago, slightly later than the 8 Ma proposed by Daly (1989). Considering that the structures of the subducted CR were as irregular as those resulting from the along-strike variations of width, topography, and crustal 
thickness of the yet, nonsubducted CR (Sallares et al., 2005), the subducted CR likely promoted a margin heterogeneous uplift pattern that controlled the development of the EC.

\section{Conclusions}

1. The EC is a 143-km-long, shelf-incising, river-connected canyon that started forming 5.3 Ma ago in response to a boost of the fore-arc uplift that is temporally correlated with the Carnegie Ridge subduction, so that this event is considered an indirect cause of the EC formation.

2. The topographic inversion of the southern half of the Manglares fore-arc basin marked by the development of the Ostiones Swell began by a change from subsidence-dominated basin floor deposits during the Early to Middle Miocene to uplift-dominated slope apron deposits during the Late Miocene-Early Pliocene.

\section{Acknowledgments}

This work was carried out in the frame of the Joint French-Ecuador Laboratory "Earthquakes and Volcanoes in the Northern Andes" and was funded by the Institut de Recherche pour le Développement (IRD), the Institut National des Sciences de l'Univers (INSU), and the Institut Francais pour l'Exploitation de la Mer (Ifremer), which provided ship time, equipment, and data processing during the Amadeus, Esmeraldas, and Atacames cruises. We acknowledge support from ANR Project ANR-15-CE04-0004 and UCA/JEDI Project ANR-15-IDEX-01. We are grateful to the Secretaria de Hydrocarburos del Ecuador (SHE) for providing us with seismic sections from the SCAN-2009 seismic experiment within the framework of the SHE-IRD cooperation agreement, as well as to the Geological Survey of Colombia for letting us use a seismic section. We thank the Instituto Oceanografico de la Armada de Ecuador (INOCAR) for providing swath bathymetric data offshore Esmeraldas, and Schlumberger for offering the use of Petrel ${ }^{\mathrm{TM}}$ software. We warmly thank J. -F. Dumont and E. Santana who successfully processed and analyzed the Amadeus dredge samples, M. Ordonez, N. Jimenez, and J. Suarez from Petroecuador, and C. Muller for their biostratigraphic analysis of the dredged samples, as well as J. F. Lebrun and B. Marcaillou for processing Amadeus seismic data. Finally, we acknowledge J. Becerra, E. Jaillard and John Geissman for their helpful comments. Amadeus multibeam bathymetry and seismic reflection data used in this work can be accessed from the French national data repository at Ifremer (http://donnees-campagnes. flotteoceanographique.fr/search) with code name Amadeus. Requirement for SCAN-2009 seismic data can be addressed to Dirección de Análisis de Información Estratégica de Hidrocarburos Av República de El Salvador N36-64 y Suecia, Quito 170135. Edificio MSP. Piso 5, Ecuador (https://www.recursosyenergia.gob.ec/ viceministerio-de-hidrocarburos).
3. Two deep incisions of the EC and the left-lateral migration of its southern half provide evidences for uplift episodes of the Ostiones Swell that are correlated with mid-Pliocene and early Pleistocene regional tectonic events. Most of the MEC, and the LEC north of latitude $1^{\circ} 28^{\prime}$ were uplifted by $300-450 \mathrm{~m}$ since the early Pleistocene in response to local and regional tectonic events, suggesting a $0.15-0.25 \mathrm{~mm} /$ year mean uplift rate. The active uplift of the Ostiones Swell and Esmeraldas Platform is supported by the $\sim 50$-m-high bulge of the EC modern thalweg across the swell.

4. Glacioeustatic variations significantly contributed to shape the EC and its upslope tributaries by increasing the rate of canyon incision likely during rapid sea level falls, thus reinforcing the effect of tectonics, which appears to be the main triggering factor for the incisions and the lateral migration of the EC.

5. Faulting and folding as well as diapiric structures have structurally controlled the location of the EC as well as the Atacames and Sua tributary canyons, whereas the Same Canyon would have initiated on a mass transport deposited in a paleoscar. The NE trending Ancon fault system and underlying splay fault controlled the AC, which has been cut from its sedimentary source $\sim 170 \mathrm{kyr}$ ago by the growth of a faultrelated anticline.

6. The EC developed on a highly unstable margin slope characterized by slump scars and MTDs, and deformed by active faulting along the Esmeraldas Platform and near the subduction front. Several MTDs plugged the canyon valley. One of them fully blocked the passage of gravity flows so that the trench turbidite sedimentation was deeply altered with less detrital deposits between $>\sim 65$ and $\sim 37 \mathrm{kyr}$.

\section{References}

Aalto, K. R., \& Miller, W. III (1999). Sedimentology of the Pliocene Upper Onzole Formation, an inner-trench slope succession in northwestern Ecuador. Journal of South American Earth Sciences, 12(1), 69-85. https://doi.org/10.1016/S0895-9811(99)00005-X

Agudelo, W., Ribodetti, A., Collot, J.-Y., \& Operto, S. (2009). Joint inversion of multichannel seismic reflection and wide-angle seismic data: Improved imaging and refined velocity model of the crustal structure of the north Ecuador-south Colombia convergent margin. Journal of Geophysical Research, 114, B02306. https://doi.org/10.1029/2008JB005690

Amblas, D., Gerber, T. P., De Mol, B., Urgeles, R., Garcia-Castellanos, D., Canals, M., et al. (2012). Survival of a submarine canyon during long-term outbuilding of a continental margin. Geology, 40(6), 543-546. https://doi.org/10.1130/G33178.1

Appelgate, B., Goldfinger, C., MacKay, M. E., Kulm, L. D., Fox, C. G., Embley, R. W., \& Meis, P. J. (1992). A left-lateral strike-slip fault seaward of the Oregon convergent margin. Tectonics, 11(3), 465-477. https://doi.org/10.1029/91TC02906

Babonneau, N., Savoye, B., Cremer, M., \& Bez, M. (2004). Multiple terraces within the deep incised Zaire Valley (ZaiAngo Project): Are they confined levees? In S. Lomas, \& P. Joseph (Eds.), Confined Turbidite Systems (pp. 91-114). London: Geological Society.

Barberi, F., Cotelli, M., Ferrara, F., Innocenti, J., Navarro, J., \& Santacroce, R. (1988). Plio-Quaternary volcanism in Ecuador. Geological Magazine, 125(1), 1-14. https://doi.org/10.1017/S0016756800009328

Baztan, J., Berne, S., Olivet, J.-L., Rabineau, M., Aslanian, D., Gaudin, M., et al. (2005). Axial incision: The key to understand submarine canyon evolution (in the western Gulf of Lion). Marine and Petroleum Geology, 22(6-7), 805-826. https://doi.org/10.1016/j. marpetgeo.2005.03.011

Bernhardt, A., Melnick, D., Jara-Muñoz, J., Argandoña, B., González, J., \& Strecker, M. R. (2015). Controls on submarine canyon activity during sea-level highstands: The Biobío canyon system offshore Chile. Geosphere, 11(4), 1226-1255. https://doi.org/10.1130/ GES01063.1

Bertoni, C., \& Cartwright, J. (2005). 3D seismic analysis of slope-confined canyons from the Plio-Pleistocene of the Ebro Continental Margin (WesternMediterranean). Basin Research, 17(1), 43-62. https://doi.org/10.1111/j.1365-2117.2005.00254.x

Cantalamessa, G., Di Celma, C., \& Ragaini, L. (2005). Sequence stratigraphy of the Punta Ballena Member of the Jama Formation (Early Pleistocene, Ecuador): Insights from integrated sedimentologic, taphonomic and paleoecologic analysis of molluscan shell concentrations. Palaeogeography, Palaeoclimatology, Palaeoecology, 216(1-2), 1-25. https://doi.org/10.1016/j.palaeo.2004.09.012

Cantalamessa, G., Di Celma, C., Ragaini, L., Valleria, G., \& Landini, W. (2007). Sedimentology and high-resolution sequence stratigraphy of the late middle to late Miocene Angostura Formation (western Borbo'n Basin, northwestern Ecuador). Journal of the Geological Society of London, 164(3), 653-665. https://doi.org/10.1144/0016-76492006-001 
Collot, J.-Y., Agudelo, W., Ribodetti, A., \& Marcaillou, B. (2008). Origin of a crustal splay fault and its relation to the seismogenic zone and underplating at the erosional N-Ecuador S-Colombia oceanic margin. Journal of Geophysical Research, 113, B12102. https://doi.org/ 10.1029/2008JB005691

Collot, J.-Y., Marcaillou, B., Sage, F., Michaud, F., Agudelo, W., Charvis, P., et al. (2004). Are rupture zone limits of great subduction earthquakes controlled by upper plate structures ?: Evidence from multichannel seismic reflection data acquired across the northern Ecuador-southwest Colombia margin. Journal of Geophysical Research, 109, B11103. https://doi.org/10.1029/2004JB003060

Collot, J.-Y., Michaud, F., Alvarado, A., Marcaillou, B., Sosson, M., Ratzov, G., et al. (2009). Vision general de la morfologia submarina del margen convergente de Ecuador-Sur de Colombia: Implicaciones sobre la transferencia de masa y la edad de la subduccion de la Cordillera de Carnegie. In J.-Y. Collot, V. Sallares, \& N. Pazmino (Eds.), Geologia y geofisica marina y terrestre del Ecuador: desde la costa continental hasta las Islas Galápagos (pp. 47-74). Guayaquil: CNDM; IRD; INOCAR, Guayaquil (ECU) ; Marseille (FRA).

Collot, J.-Y., Migeon, S., Spence, G., Legonidec, Y., Marcaillou, B., Schneider, J.-L., et al. (2005). Seafloor margin map helps in understanding subduction earthquakes, EOS. Transactions of the American Geophysical Union, 86(46), 464-466.

Covault, J. A., Fildani, A., Romans, B. W., \& McHargue, T. (2011). The natural range of submarine canyon-and-channel longitudinal profiles. Geosphere, 7(2), 313-332. https://doi.org/10.1130/GES00610.1

Covault, J. A., Normark, W. R., Roman, B. W., \& Graham, S. A. (2007). Highstand fans in the California borderland: The overlooked deepwater depositional systems. Geology, 35(9), 783-786. https://doi.org/10.1130/G23800A.1

Daly, M. (1989). Correlations between Nazca/Farallon plate kinematics and forearc basin evolution in Ecuador. Tectonics, 8(4), 769-790. https://doi.org/10.1029/TC008i004p00769

Deniaud, Y. (2000). Enregistrements sédimentaire et structural de l'évolution géodynamique des Andes Equatoriennes au cours du Néogène: Etude des bassins d'avant-arc et bilans de masse., PhD thesis, (p. 157). Grenoble: Université Joseph Fourier.

Deptuck, M. E., Sylvester, Z., Pirmez, C., \& Byrne, C. O. (2007). Migration-aggradation history and 3-D seismic geomorphology of submarine channels in the Pleistocene Benin-major Canyon, western Niger Delta slope. Marine and Petroleum Geology, 24(6-9), 406-433. https://doi.org/10.1016/j.marpetgeo.2007.01.005

Di Celma, C., Cantalamessa, G., Landini, W., \& Ragaini, L. (2010). Stratigraphic evolution from shoreface to shelf-indenting channe depositional systems during transgression: Insights from the lower Pliocene Súa Member of the basal Upper Onzole Formation, Borbón Basin, northwest Ecuador. Sedimentary Geology, 223(1-2), 162-179. https://doi.org/10.1016/j.sedgeo.2009.11.009

Evans, C. D. R., \& Wittaker, J. E. (1982). The geology of the western part of the Borbon Basin, northwest Ecuador: trench forearc geology. Geological Society of London, 10(1), 191-198. https://doi.org/10.1144/GSL.SP.1982.010.01.12

Farre, J. A., Mcgregor, B. A., Ryan W. B. F., Robb, J. M., Stanley, D. J., \& Moore, G. T. (1983). Breaching the shelfbreak; passage from youthful to mature phase in submarine canyon evolution. The Shelfbreak; Criticial Interface on Continental Margins, Special Publications, Society of Economic Paleontologists and Mineralosgists (Vol. 33, pp. 25-39).

Gastaud, S. (2010). Analyse des transferts sédimentaires dans le bassin de Manglares, Master 2 Recherche thesis, (p. 55). Nice, France: Université de Nice Sophia-Antipolis.

Gossens, P. J., \& Rose, W. I. (1973). Chemical composition and age determination of tholeiitic rocks in the basic igneous complex, Ecuador. Geological Society of America Bulletin, 84(3), 1043-1052. https://doi.org/10.1130/0016-7606(1973)84<1043:CCAADO>2.0.CO;2

Greene, H. G., Clarke, S. H. Jr., \& Kennedy, M. P. (1991). Tectonic evolution of submarine canyons along the California continental margin. In R. H. Osborne (Ed.), Shoreline to abyss: Contributions in marine geology in honor of Francis Parker Shepard., edited by, Special Publication (Vol. 46, pp. 231-248). SEPM, Tulsa, Oklahoma.

Gripp, A. E., \& Gordon, R. G. (2002). Young tracks of hotspots and current plate velocities. Geophysical Journal International, 150(2), 321-361. https://doi.org/10.1046/j.1365-246X.2002.01627.x

Gutscher, M. A., Malavieille, J., Lallemand, S., \& Collot, J. Y. (1999). Tectonic segmentation of the North Andean margin: Impact of the Carnegie Ridge collision. Earth and Planetary Science Letters, 168(3-4), 255-270. https://doi.org/10.1016/S0012-821X(99)00060-6

Hagen, R. A., Vergara, H., \& Naar, D. F. (1996). Morphology of San Antonio submarine canyon on the central Chile forearc. Marine Geology, 129(3-4), 197-205. https://doi.org/10.1016/0025-3227(96)83345-7

Hansen, J., Sato, M., Russell, G., \& Kharecha, P. (2013). Climate sensitivity, sea level and atmospheric carbon dioxide. Philosophical Transactions of the Royal Society of London. Series A, 371(2001). https://doi.org/10.1098/rsta.2012.0294

Harris, P., \& Whiteway, T. (2011). Global distribution of large submarine canyons: Geomorphic differences between active and passive continental margins. Marine Geology, 285(1-4), 69-86. https://doi.org/10.1016/j.margeo.2011.05.008

Heller, P. L., \& Dickinson, W. R. (1985). Submarine ramp facies model for delta-fed, sand-rich turbidite systems. American Association of Petroleum Geologists Bulletin, 69(6), 960-976.

Heuret, A., \& Lallemand, S. (2005). Plate motions, slab dynamics and back-arc deformation. Physics of the Earth and Planetary Interiors, 149(1-2), 31-51. https://doi.org/10.1016/j.pepi.2004.08.022

Huyghe, P., Foata, M., Deville, E., Mascle, G., \& Caramba Working Group (2004). Channel profiles through the active thrust front of the southern Barbados prism. Geology, 32, 429-432.

Jaillard, E., Ordo\&ntilde;ez, M., Benitez, S., Berrones, G., Jimenez, N., Montenegro, G., \& Zambrano, I. (1995). Basin Development in an accretionary, oceanic-floored fore-arc setting: Southern coastal Ecuador during late Cretaceous-Late Eocene Time. In A. J. Tankard, S. Suarez Soruco, \& H. J. Welskin (Eds.), Petroleum Basins of South America: AAPG Memoir 62 (pp. 615-631). Tulsa: American Association of Petroleum Geologists

Joanne, C., Collot, J.-Y., Lamarche, G., \& Migeon, S. (2010). Continental slope reconstruction after a giant mass failure, the example of the Matakaoa Margin, New Zealand. Marine Geology, 268(1-4), 67-84. https://doi.org/10.1016/j.margeo.2009.10.013

Joanne, C., Lamarche, G., \& Collot, J.-Y. (2013). Dynamics of giant mass transport in deep submarine environments: the Matakaoa Debris Flow, New Zealand. Basin Research, 25(4), 471-488. https://doi.org/10.1111/bre.12006

Juteau, T., Mégard, F., Raharison, F., \& Whitechurch, H. (1977). Les assemblages ophiolitiqes de l'Occident équatorien: Nature pétrographique et position structurale. Bulletin de la Societe Geologique de France, 7(19), 1127-1132.

Kanamori, H., \& McNally, K. C. (1982). Variable rupture mode of the subduction zone along the Ecuador-Colombia coast. Bulletin of the Seismological Society of America, 72(4), 1241-1253.

Kukowski, N., Schillhorn, T., Huhn, K., von Rad, U., Husen, S., \& Flueh, E. R. (2001). Morphotectonics and mechanics of the central Makran accretionary wedge off Pakistan. Marine Geology, 173(1-4), 1-19. https://doi.org/10.1016/S0025-3227(00)00167-5

Lallemand, S., Heuret, A., \& Boutelier, D. (2005). On the relationships between slab dip, back-arc stress, upper plate absolute motion, and crustal nature in subduction zones. Geochemistry, Geophysics, Geosystems, 6, Q09006. https://doi.org/10.1029/2005GC000917

Laursen, J., \& Normark, W. R. (2002). Late Quaternary evolution of the San Antonio Submarine Canyon in the Central Chile forearc ( 33 S). Marine Geology, 188(3-4), 365-390. https://doi.org/10.1016/S0025-3227(02)00421-8 
Leclerc, P. (2016). Paléosismologie de la subduction Equateur/Colombie à partir de l'analyse détaillée des turbidites, Master 1 thesis. France: Université de Perpignan.

Leopold, L. B., and M. G. Wolman (1957), River channel pattern: Braided, meandering, and straight, US Geological Survey Professional Paper 282-B, 39-84,

Lonsdale, P. (1978). Ecuadorian subduction system. American Association of Petroleum Geologists Bulletin, 62(12), $2454-2477$.

Lopez Ramos, E. (2009). Evolution tectono-stratigraphique du double bassin avant-Arc de la marge convergente Sud Colombienne-Nord Equatorienne pendant le Cénozoïque, (p. 349). Nice, France: Université de Nice Sophia Antipolis. https://doi.org/10.13140/ RG.2.2.14321.12642

Manchuel, K., Régnier, M., Béthoux, N., Font, Y., Sallarès, V., Díaz, J., \& Yepes, H. (2011). New insights on the interseismic active defor mation along the North Ecuadorian-South Colombian (NESC) margin. Tectonics, 30, TC4003. https://doi.org/10.1029/2010TC002757

Marcaillou, B., \& Collot, J.-Y. (2008). Chronostratigraphy and tectonic deformation of the North Ecuador-South Colombian fore-arc basin Marine Geology, 255(1-2), 30-44. https://doi.org/10.1016/j.margeo.2008.07.003

Marcaillou, B., Collot, J.-Y., Ribodetti, A., d'Acremont, E., Mahamat, A.-A., \& Alvarado, A. (2016). Seamount subduction at the NorthEcuadorian convergent margin: Effects on structures, inter-seismic coupling and seismogenesis. Earth and Planetary Science Letters, 433 , 146-158.

Marcaillou, B., Spence, G., Wang, K., Collot, J.-Y., \& Ribodetti, A. (2008). Thermal segmentation along the North Ecuador-South Colombia margin $\left(1^{\circ}-4^{\circ} \mathrm{N}\right)$ : Prominent influence of sedimentation rate in the trench. EPSL, 272(1-2), 296-308. https://doi.org/10.1016/j. epsl.2008.04.049

Menard, H. W. (1955). Deep-sea channels, topography, and sedimentation. American Association of Petroleum Geologists Bulletin, 39, 236-255.

Mendoza, C., \& Dewey, J. W. (1984). Seismicity associated with the great Colombia-Ecuador earthquakes of 1942, 1958 and 1979: Implications for barrier models of earthquake rupture. Bulletin of the Seismological Society of America, 74(2), 577-593.

Michaud, F., Proust, J. N., Collot, J. Y., Lebrun, J. F., Witt, C., Ratzov, G., et al. (2015). Quaternary sedimentation and active faulting along the Ecuadorian shelf: Preliminary results of the ATACAMES Cruise (2012). Marine Geophysical Researches, 36(1), 81-98. https://doi. org/10.1007/s11001-014-9231-y

Migeon, S., Garibaldi, C., Ratzov, G., Schmidt, S., Collot, J.-Y., Zaragosi, S., \& Texier, L. (2017). Earthquake-triggered deposits in the subduction trench of the north Ecuador/south Colombia margin and their implication for paleoseismology. Marine Geology, 384, 47-62. https://doi.org/10.1016/j.margeo.2016.09.008

Miller, K., Kominz, M. A., Browning, J. V., Wright, J. D., Mountain, G. S., Katz, G. S., et al. (2005). The Phanerozoic record of global sealevel change. Science, 310(5752), 1293-1298. https://doi.org/10.1126/science.1116412

Mountjoy, J., Barnes, P. M., \& Pettinga, J. R. (2009). Morphostructure and evolution of submarine canyons across an active margin: Cook Strait sector of the Hikurangi Margin, New Zealand. Marine Geology, 206, 45-68.

Mountney, N. P., \& Westbrook, G. K. (1997). Quantitative analysis of Miocene to recent forearc basin evolution along the Colombian margin. Basin Research, 9(3), 177-196. https://doi.org/10.1046/j.1365-2117.1997.00040.x

Nocquet, J.-M., Jarrin, P., Vallée, M., Mothes, P. A., Grandin, R., Rolandone, F., et al. (2016). Supercycle at the Ecuadorian subduction zone revealed after the 2016 Pedernales earthquake. Nature Geoscience, 10(2), 145-149. https://doi.org/10.1038/NGEO2864

Nocquet, J.-M., Villegas-Lanza, J. C., Chlieh, M., Mothes, P. A., Rolandone, F., Jarrin, P., et al. (2014). Motion of continental slivers and creeping subduction in the northern Andes. Nature Geoscience, 7(4), 287-291. https://doi.org/10.1038/NGEO2099

Noda, A., Tuzino, T., Furukawa, R., Joshima, M., \& Uchida, J. (2008). Physiographical and sedimentological characteristics of submarine canyons developed upon an active forearc slope: The Kushiro submarine canyon, northern Japan. Geological Society of America Bulletin, 120(5-6), 750-767. https://doi.org/10.1130/B26155.1

Normark, W. R., \& Carlson, P. C. (2003). Giant submarine canyons: Is size any clue to their importance in the rock record ? Geological Society of America Bulletin, 370, 1-15.

Ordonez, M., Jimenez, N., \& Suarez, J. (2006). Micropaleontologia Ecuatoriana; Datos bioestratigràficos y paleoecologicos de las cuencas: Graben de Jambeli, Progresso, Manabi, Esmerladas y Oriente; del leventamiento de la Peninsula de Santa Elena, y de las cordilleras Chongon Colonche Costero y Occidental, edited by Centro de Investigaciones Geologicas Guayaquil, (p. 634). Petroproduccion, Guayaquil, Ecuador.

Pardo-Casas, F., \& Molnar, P. (1987). Relative motion of the Nazca (Farrallon) and South America plates since Late Cretaceous time. Tectonics, 6(3), 233-248. https://doi.org/10.1029/TC006i003p00233

Pedoja, K., Ortlieb, L., Dumont, J. F., Lamothe, M., Ghaleb, B., Auclair, M., \& Labrousse, B. (2006). Quaternary coastal uplift along the Talara Arc (Ecuador, Northern Peru) from new marine terrace data. Marine Geology, 228(1-4), 73-91. https://doi.org/10.1016/j. margeo.2006.01.004

Piper, D. J. W., Cochonat, P., \& Morrison, M. L. (1999). The sequence of events around the epicentre of the 1929 grand banks earthquake: Initiation of debris flows and turbidity current inferred from sidescan sonar. Sedimentology, 46(1), 79-97. https://doi.org/10.1046/j.13653091.1999.00204.x

Pratson, L. F., \& Coakley, B. J. (1996). A model for the headward erosion of submarine canyons induced by downslope-eroding sediment flows. Geological Society of America Bulletin 108(2), 225-234.

Pratson, L. F., Ryan, W. B. F., Mountain, G. S., \& Twichell, D. C. (1994). Submarine canyon initiation by downslope-eroding sediment flows: Evidence in late Cenozoic strata on the New Jersey continental slope. Geological Society of America Bulletin, 106(3), 395-412. https://doi.org/10.1130/0016-7606(1994)106<0395:SCIBDE $>2.3 . C O ; 2$

Rasmussen, E. S. (1994). The relationship between submarine canyon fill and sea-level change: An example from Middle Miocene offshore Gabon, West Africa. Sedimentary Geology, 90(1-2), 61-75. https://doi.org/10.1016/0037-0738(94)90017-5

Ratzov, G., J. Y. Collot, S. Migeon, B. Marcaillou, and J. F. Lebrun (2011), Evidences for a sub-marine active fault along the North-Ecuador South Colombia oblique-convergent margin: implication for fault maturity and tectonic escape, in European Geosciences Union General Assembly, vol 13, EGU2011-9926, edited, Vienna, Austria.

Ratzov, G., Collot, J.-Y., Sosson, M., \& Migeon, S. (2010). Mass-transport deposits in the northern Ecuador subduction trench: Result of frontal erosion over multiple seismic cycles. Earth and Planetary Science Letters, 296, 89-102.

Ratzov, G., Sosson, M., Collot, J.-Y., \& Migeon, S. (2012). Late Quaternary geomorphologic evolution of submarine canyons as a marker of active deformation on convergent margins: The example of the South Colombian margin. Marine Geology, 315-318, 77-97. https://doi org/10.1016/j.margeo.2012.05.005

Ratzov, G., M. Sosson, J.-Y. Collot, S. Migeon, F. Michaud, E. Lopez, and Y. Le Gonidec (2007), Submarine landslides along the North Ecuador-South Colombia convergent margin. Possible tectonic control, paper presented at Third International Symposium on Submarine Mass Movements and Their Consequences, KLUWER-SPRINGER Bookseries, Santorini (GREECE), 1-3rd October 2007. 
Restrepo-Correa, I. C., \& Ojeda, G. Y. (2010). Geologic controls on the morphology of La Aguja submarine canyon. Journal of South American Earth Sciences, 29(4), 861-870. https://doi.org/10.1016/j.jsames.2010.07.001

Reyes, P. (2013), Évolution du relief le long des marges actives: Etude de la déformation Plio-Quaternaire de la cordillère côtière d'Equateur, PhD thesis, 279 pp, Université de Nice-Sophia Antipolis, Nice, France, https://tel.archives-ouvertes.fr/tel-00835324

Reyes, P., and F. Michaud (2012), Mapa Geologico de la Margen Costera Ecuatoriana (1/1500000), EPPetroEcuador-IRD Quito, Ecuador.

Reynaud, C., Jaillard, E., Lapierre, H., Mamberti, M., \& Mascle, G. H. (1999). Oceanic plateau and island arcs of southwestern Ecuador: Their place in the geodynamic evolution of northwestern South America. Tectonophysics, 307(3-4), 235-254. https://doi.org/10.1016/ S0040-1951(99)00099-2

Sage, F., Collot, J.-Y., \& Ranero, C. R. (2006). Interplate patchiness and subduction-erosion mechanisms: Evidence from depth migrated seismic images at the central Ecuador convergent margin. Geology, 34(12), 997-1000. https://doi.org/10.1130/G22790A.1

Sallares, V., Charvis, P., Flueh, E. R., Bialas, J., \& scientific party Salieri (2005). Seismic structure of the Carnegie Ridge and the nature of the Galàpagos Hotspot. Geophysical Journal International, 161(3), 763-788. https://doi.org/10.1111/j.1365-246X.2005.02592.x

Shanmugam, G. (2016). Submarine fans: A critical retrospective (1950-2015). Journal of Paleogeography, 5(2), 110-184. https://doi.org/ 10.1016/j.jop.2015.08.011

Shepard, F. P. (1981). Submarine canyons: Multiple causes and long-time persistence. American Association of Petroleum Geologists Bulletin, 65, 1062-1077.

Silva Chamorro, P. A. (2007). Análisis morfológico y estructural del cañón submarino del río Esmeraldas a partir de datos de geofisica marina Ingeniero geologo thesis, (p. 179 p. multigr). Quito, Ecuador: Escuela Politécnica Nacional.

Somoza, R., \& Ghidella, M. E. (2012). Late Cretaceous to recent plate motions in western South America revisited. Earth and Planetary Science Letters, 331-332, 152-163. https://doi.org/10.1016/j.epsl.2012.03.003

Spikings, R. A., Crowhurst, P. V., Winkler, W., \& Villagomez, D. (2010). Syn- and post-accretionary cooling history of the Ecuadorian Andes constrained by their in-situ and detrital thermochronometric record. Journal of South American Earth Sciences, 30(3-4), 121-133. https:// doi.org/10.1016/j.jsames.2010.04.002

Stow, D. A. V., \& Mayall, M. (2000). Deep-water sedimentary systems: New models for the 21st century. Marine and Petroleum Geology, 17(2), 125-135. https://doi.org/10.1016/S0264-8172(99)00064-1

Sylvester, Z., Pirmez, C., \& Cantelli, A. (2011). A model of submarine channel-levee evolution based on channel trajectories: Implications for stratigraphic architecture. Marine and Petroleum Geology, 28(3), 716-727. https://doi.org/10.1016/j.marpetgeo.2010.05.012

Trenkamp, R., Kellogg, J. N., Freymueller, J. T., \& Mora, P. (2002). Wide plate margin deformation, southern Central America and northwestern South America, CASA GPS observations. Journal of South American Earth Sciences, 15(2), 157-171. https://doi.org/ 10.1016/S0895-9811(02)00018-4

Vacherat, A., S. Brichau, P. Reyes, F. Michaud, J. N. Proust, and M. J. Hernandez (2017), First constraints on the timing of the Ecuadorian Coastal Cordillera uplift and geodynamic implications, paper presented at EGU General Assembly Conference Vienna, Austria.

Wessel, P., \& Smith, W. D. (1998). New, improved version of Generic Mapping Tools Released. Eos, Transactions American Geophysical Union, 79(47), 579. https://doi.org/10.1029/98EO00426

Yilmaz, O. (2001), Seismic data analysis. Processing, inversion and interpretation of seismic data. 2065 pp., Society of Exploration Geophysicist.

\section{Erratum}

In the originally published version of this article, a duplicate Figure 17 erroneously published as Figure 7. Figure 7 has since been corrected, and this version may be considered the authoritative version of record. 